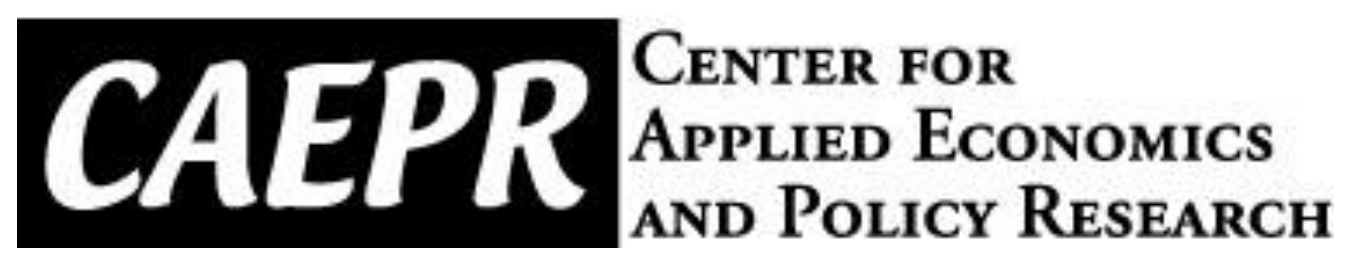

CAEPR Working Paper

\#2012-006

\title{
A Macroeconomic Analysis of Energy Subsidies in a Small Open Economy: The Case of Egypt
}

\author{
Gerhard Glomm \\ Indiana University \\ Juergen Jung \\ Towson University
}

April 9, 2012

This paper can be downloaded without charge from the Social Science Research Network electronic library at: http://ssrn.com/abstract=2037843.

The Center for Applied Economics and Policy Research resides in the Department of Economics at Indiana University Bloomington. CAEPR can be found on the Internet at: http://www.indiana.edu/ caepr. CAEPR can be reached via email at caepr@indiana.edu or via phone at 812-855-4050.

(C2012 by Gerhard Glomm and Juergen Jung. All rights reserved. Short sections of text, not to exceed two paragraphs, may be quoted without explicit permission provided that full credit, including $($ notice, is given to the source. 


\title{
A Macroeconomic Analysis of Energy Subsidies in a Small Open Economy: The Case of Egypt*
}

\author{
Gerhard Glomm ${ }^{\dagger}$ \\ Juergen Jung $\ddagger$ \\ Indiana University \\ Towson University
}

8th April 2012

\begin{abstract}
We construct a dynamic general equilibrium model to analyze the effects of large energy subsidies in a small open economy. The model pays special attention to domestic energy production and consumption, trade in energy at world market prices, as well as private and public sector production including the provision of public infrastructure. The model is calibrated to data from Egypt and then used to study policy reforms such as reductions in energy subsidies with corresponding reductions in consumption taxes, labor taxes, capital taxes, or increases in infrastructure investment. We calculate the new steady states, the transition paths to the new steady state and the size of the associated welfare losses or gains. In response to a 15 percent cut in energy subsidies, GDP may fall as less energy is used in production. Excess energy is exported and capital imports are reduced. Welfare in consumption equivalent terms can rise by up to 0.6 percent of GDP. Gains in output can be realized only if the government re-invests into infrastructure.
\end{abstract}

JEL Classification: E21, E63, H55, J26, J45

Keywords: energy subsidies, fiscal policy reform, public sector reform, growth

*This project was supported by the World Bank. The content is solely the responsibility of the authors and does not necessarily represent the official views of the World Bank and its agencies. We would like to thank Santiago Herrera, Sherine Al-Shawarby, Jialu Liu, and participants of the 2012 Annual Meeting of the Midwest Economic Association for helpful comments and Di Wu for valuable research assistance. All remaining errors are ours.

†Corresponding Author: Gerhard Glomm, Department of Economics, Wylie Hall, Indiana University, Bloomington, IN, 47405, phone: (812) 855-7256, e-mail: gglomm@indiana.edu

$\ddagger$ Department of Economics, Towson University. Contact: jjung@towson.edu 


\section{Introduction}

A report by the International Energy Agency (IEA) in 2010 identified 37 countries that together account for 95 percent of global subsidized fossil-fuel consumption and found that total fuel consumption subsidies were about $\$ 557$ billion in 2008 , a stark increase from $\$ 342$ billion in 2007 (IEA (2010b), IEA (2010c)). Countries with the highest subsidies for energy turn out to be smaller, oil producing countries like Iran ( $\$ 101$ billion in subsidies in 2008, a third of GDP), Saudi Arabia, Venezuela, and Egypt (compare figure 1). The underpricing of energy can lead to excess consumption of energy that together with the need to finance these subsidies can have adverse economic effects, both intraand intertemporally. Energy subsidies may therefore have large adverse effects on capital accumulation, economic growth, and hence welfare, especially for future generations. The IEA estimates that many countries forgo faster growth by subsidizing energy. Figure 2 shows estimates of growth effects triggered by cutting energy subsidies in various countries reported in IEA (2010a). Since 2008 many major oil subsidizing countries have started to bring their prices in line with world market prices, among them are China, Russia, India and Indonesia.

We revisit this issue and use a dynamic general equilibrium model to analyze how cuts in energy subsidies can affect a small open economy with a large domestic energy sector in terms of growth and welfare. At the outset of this enterprise it is useful to take stock of the particular fiscal policy situation in Egypt as cuts in energy subsidies will affect the balance sheet of the government. Energy extraction and production play a crucial role in the Egyptian economy. The energy sector accounts for about 20 percent of total GDP. Of course this number is subject to considerable fluctuations given the observed large variation in world energy prices and the finiteness of energy stocks underground. Associated with the energy sector is a large and important system of subsidies. These types of subsidies are not limited to the energy sector but extend also to food and other commodities. Total commodity subsidies account for close to 7 percent of GDP, with energy subsidies making up around 77 percent of all commodity subsidies, which is about 5.4 percent of GDP. The size of the public sector in production in Egypt is large whether measured in terms of output, investment or employment relative to the respective total. Public sector employment is around 25 percent of total employment and public investment has in the past exceeded private investment. This large public involvement is especially pronounced in the petroleum markets where both the public investment and public employment shares have reached over 65 percent.

We study the effects of a decrease in domestic energy subsidies for households and for firms under various tax adjustment cases. We use a dynamic general equilibrium model with overlapping generations, a public sector, and an energy sector. In addition, we distinguish between low and high income earners. We consider a small open economy

model where capital and energy are traded at given world market prices. Since we leave the world market prices for energy constant, our findings are not directly comparable to 
estimates by the IEA that try to factor in decreases in "global" cuts of energy subsidies (see figure 2).

We first calibrate parameters using data from Egypt and solve the model for a steady state equilibrium. We then impose cuts to energy subsidies to households and firms and solve for the new, post-reform, steady state where the government can use the freed up funds to either lower taxes or boost infrastructure investments. We then compare economic aggregates across the two steady states. We find that decreases in energy subsidies can cause output to decrease. The cuts to energy subsidies for producers lower the rate of return to physical capital so that less physical capital is used in production. This allows the economy to lower its imports of physical capital. The entire economy shrinks and energy that was previously consumed by domestic households and used in domestic production of goods and services will be simply exported at fixed world market prices.

This somewhat surprising result demonstrates that without developing an alternative energy sector or more efficient usage of energy in the final goods production sector, cuts in energy subsidies in developing or emerging economies like Egypt can have adverse effects on growth but not welfare. We calculate various welfare measures using solutions obtained from calculating the transition path from the old to the new equilibrium. This also allows us to distinguish the welfare effects of young vs. old, rich vs. poor, and private vs. public sector workers. We then demonstrate alternative reforms that can equally reduce government spending and therefore the tax burden without adversely affecting output. Many of the policy effects are mitigated by the small open economy assumption that allows capital and energy to be traded internationally at fixed prices.

Literature. At least since the 1990s have formal dynamic general equilibrium models been used to study the influence of fiscal policy on capital accumulation, economic growth, long run levels of income, and welfare. Examples of this literature include Barro (1990), Saint-Paul (1992), Glomm and Ravikumar (1997), Turnovsky (2000), Blankenau and Simpson (2004) and many others. Calibrated versions of these types of models have been used to asses the quantitative effects of particular fiscal policy reforms on economic growth. Most of these calibration exercises are done in the context of the US economy. These papers include Lucas (1990), Glomm and Ravikumar (1998) and many others. In these models a typical result is that the effect of tax reform on growth can be very small as in Lucas (1990), for example, while growth effects of changes in public expenditures on infrastructure and public education, to name just a few, can be larger. See for example Baier and Glomm (2001).

There is now a small literature on the connection between energy consumption, pollution, energy prices and macroeconomic variables such as economic growth. Brock and Taylor (2010), for example, combine technological progress in an environmental abatement technology with a standard version of the Solow growth model and are able to generate the environmental Kuznets curve as an equilibrium outcome. Smulders and de Nooij (2003) study the connection between energy conservation policies and long-run 
economic growth. Moon and Sonn (1996) use a growth model to investigate the connection between energy expenditures and economic growth. Peretto (2009) shows that the connection between energy taxes and economic growth depends upon the precise interplay of the demand elasticities for energy and technological progress.

Similar to Peretto (2009) a part of the literature on the double dividend hypothesis of green taxes investigates the connection between energy taxes/subsidies and capital accumulation. Glomm, Kawaguchi and Sepulveda (2008) use a calibrated version of a growth model to study the complementary use of energy and physical capital in production to obtain predictions concerning energy taxes/subsidies and transitional economic growth.

The papers closest to the present one are Pereira and Pereira (2011a), Pereira and Pereira (2011b) who study a growth model with an energy sector that is calibrated to data from Portugal to investigate the connection between energy prices and macroeconomic variables as well as Plante (2011) who studies the impact of energy subsidies in oil importing developing countries. One fundamental difference between their papers and ours is that they study an oil importing economy while we focus on Egypt, which is a net exporter of oil.

The paper is organized as follows. The next section describes the model. In section 3 we calibrate the model to Egypt and in section 4 we conduct policy experiments. Section 5 provides a discussion of the results and concludes. The appendix contains all tables and figures. A separate technical appendix, available upon request from the authors, contains the details for all the model solutions and the welfare calculations.

\section{The model}

\subsection{Heterogeneity}

There is a large number of individuals who live for $J$ periods in an overlapping generations economy. The economy is open so that many prices (i.e. interest rates and the price of energy) are exogenous. We do not allow for labor migration. Each period accounts for $\frac{70}{J}$ years, with working life beginning at age 20 and life ending for sure at age 90 . Workers are born with an innate ability that determines their income. This income type cannot be changed. In addition, workers can either work in the public sector (civil servants etc.) or in the private sector. We denote the income type as variable income and the working sector as variable sector $\in\{$ Private, Government $\}$. The agent is then characterized by age, income type, and working sector. We summarize this information in state vector $\theta=\{$ income, sector $\}$. Here and in the rest of the paper the subscripts $P$ and $G$ denote private sector workers and public sector workers respectively. When we need to distinguish between the sectors we fix the sector variable to one of the sectors and use the following state vector notation $\theta_{P}=\{$ income, sector $=$ Private $\}$ and $\theta_{G}=\{$ income, sector $=$ Government $\}$. 


\subsection{Demographics}

Agents have a random life time. At each age, agents face a mortality shock with a given survival probability $\pi_{j}$. Population grows exogenously at net rate $n$. We assume stable demographic patterns so that, similar to Huggett (1996), age $j$ agents make up a constant fraction $\mu_{j, t}$ of the entire population at any point in time $t$. Variable $\mu_{j}(\theta)$ denotes the mass of age $j$ agents with characteristic $\theta$. We normalize the population in each time period to one so that aggregate variables correspond to per capita values. It then has to hold that $\sum_{j=1}^{J} \sum_{\theta} \mu_{j, t}(\theta)=1$. The relative size of each age cohort $\mu_{j, t}=\sum_{\theta} \mu_{j, t}(\theta)$ is recursively defined as

$$
\mu_{j, t}=\frac{\pi_{j}}{(1+n)} \mu_{j-1, t}
$$

Similarly, the cohort size of agents dying each period (conditional on survival up to the previous period) can be defined recursively as

$$
v_{j, t}=\frac{1-\pi_{j}}{(1+n)} \mu_{j-1, t}
$$

In the following we will drop the calendar time subscript $t$ whenever possible to not clutter the notation.

\subsection{Human capital}

Agents are endowed with one unit of time each period and they provide $\left(1-l_{j}\right)$ units of time to the labor market with age dependent efficiency $e_{j}(\theta)$. Effective labor (or human capital) at each age is given by $h_{j}(\theta)=\left(1-l_{j}\right) e_{j}(\theta)$. This varies over the life-cycle following the typical hump-shaped pattern.

\subsection{Preferences and technology}

Within each period of their lives agents value a numeraire consumption good $c$, energy $m_{C}$, and leisure $l$ according to the period utility function

$$
u\left(c, l, m_{C}\right)
$$

This function has the standard properties of monotonicity and quasi-concavity. Utility is discounted at the rate $\beta$.

Physical capital depreciates at rate $\delta$ each period and can be used in the production of the final consumption good and the production of energy, so that

$$
K=K_{P}+K_{M}
$$

where $K_{P}$ is physical capital used in the production of final consumption goods and services and $K_{M}$ is physical capital used in the production of energy. 
Final consumption and services are produced from four inputs, a public good $G$, physical capital stock $K_{P}$, effective labor (human capital) in the private sector $H_{P}$, and energy $M_{P}$ according to the production function

$$
Y=F_{P}\left(G, K_{P}, H_{P}, M_{P}\right) .
$$

This production function is homogenous of degree one in $K_{P}, H_{P}$, and $M_{P}$. The public good in the production function can be thought of as the stock of public infrastructure such as roads. This public good is made available to all firms at a zero price. Specifications of the technology similar to this one have been used by Barro (1990), Turnovsky (1999) and others. Total factor productivity grows exogenously at rate $g$.

The intermediate good (energy) is produced using capital $K_{M}$ and human capital $H_{M}$ according to

$$
M=F_{M}\left(K_{M}, H_{M}\right) .
$$

Profits of energy production, if any, are redistributed to the government.

The government uses effective labor (human capital) of civil servants $H_{G}$ and public capital $K_{G}$ to produce infrastructure capital according to

$$
G=F_{G}\left(K_{G}, H_{G}\right) .
$$

This production function is characterized by the properties of monotonicity, concavity, and homogeneity of degree one. This set-up allows us to not only study the costs of public sector compensation including pension benefits but also the benefits of public sector employment.

Public capital evolves according to

$$
K_{G, t+1}=\frac{1}{(1+n)(1+g)}\left(\left(1-\delta_{G}\right) K_{G, t}+I_{G, t}\right),
$$

where we detrend capital with the exogenous population growth rate and the exogenous technological growth rate. Public capital depreciates at rate $\delta_{G}$ in each period and $I_{G, t}$ is investment in the public capital in period $t$.

\subsection{Labor markets and government}

Labor markets. We assume that workers cannot migrate, so that labor markets are closed. At the beginning of their life, workers are selected into employment in either the public or private sector. We assume that for all cohorts in all time periods public sector wages exceed those in the private sector by factor $\xi^{W}>1$ in order to mimic the more generous public sector compensation scheme. Hence all workers prefer public sector jobs to jobs in the private sector. We maintain the assumption that all workers of a given age and type are equally productive regardless of whether they work in the public or private 
sector. All workers will retire at age $J_{1}$ irrespective of the sector they are working in. We think of this as the standard retirement age, i.e. age 60 .

Government expenditures. The government finances investment in public capital $I_{G}=\Delta_{G} \times G D P$, where $\Delta_{G}$ is the fraction of GDP allocated to public investments. ${ }^{1}$ The remainder of government expenditure is government consumption $C_{G}$. We let $C_{G}=$ $\Delta_{C_{G}} Y$. Government consumption is assumed to be unproductive.

The government uses public capital and hires labor to produce public goods. The fraction of civil servants is fixed exogenously at $N^{G}$ as a matter of government policy. The total wage bill of currently employed civil servants is

$$
\text { Wage }_{G}=\sum_{\theta_{G}} \sum_{j=1}^{J_{1}} w_{G} h_{j}\left(\theta_{G}\right) \mu_{j}\left(\theta_{G}\right)
$$

The wages of civil servants are set by the government using a markup $\xi^{W}>1$ over private sector wages so that $w_{G}=\xi^{W} \times w_{P}$. Private sector wages are determined by the market.

The government runs two separate pension programs, one for public sector workers and one for private sector workers. All workers of both sectors are required to participate in the pension program and consequently have to pay a social security $\operatorname{tax} \tau_{S S}^{P}$ and $\tau_{S S}^{G}$. When workers retire they stop paying labor taxes and social security taxes and are eligible to draw pension benefits. We summarize the payout formula to private sector retirees as

$$
\operatorname{Pen}_{j}\left(\theta_{P}\right)=\Psi_{P} \times \frac{1}{J_{1}} \sum_{j=1}^{J_{1}} w_{P, t-J_{1}+j} \times h_{j, t-J_{1}+j}\left(\theta_{P}, j\right)
$$

and the payout formula to public sector retirees as

$$
\operatorname{Pen}_{j}\left(\theta_{G}\right)=\Psi_{G} \times \frac{1}{J_{1}} \sum_{j=1}^{J_{1}} w_{G, t-J_{1}+j} \times h_{j, t-J_{1}+j}\left(\theta_{G}, j\right) .
$$

Note that the payout formula is a function of the workers average earnings, where $\Psi_{P}$ and $\Psi_{G}$ stands for the pension replacement rate in the private and public sector respectively.

In addition, the pension scheme for public sector workers differs from the scheme for private sector workers in contribution rates and benefit payments. The total pension payouts for private sector retirees and for public sector retirees are given by

$$
\operatorname{Pen}_{P}=\overbrace{\sum_{\theta_{P}} \sum_{j=J_{1}+1}^{J} \operatorname{Pen}_{j}\left(\theta_{P}\right) \mu_{j}\left(\theta_{P}\right)}^{\text {total pensions private sector workers }}
$$

\footnotetext{
${ }^{1} G D P$ in the model is defined as the sum of private sector output $Y$ and private consumption of energy $p_{M} M_{C}$.
} 
and

$$
\operatorname{Pen}_{G}=\overbrace{\sum_{\theta_{G}} \sum_{j=J_{1}+1}^{J} \operatorname{Pen}_{j}\left(\theta_{G}\right) \mu_{j}\left(\theta_{G}\right)}^{\text {total pensions public sector workers }} .
$$

Government income. The government collects labor income taxes from all workers in the private and public sector at the rates $\tau_{L}^{P}$ and $\tau_{L}^{G}$ as well as social security taxes $\tau_{S S}^{P}$ and $\tau_{S S}^{G}$. Accidental bequests are taxed at $\tau_{B e q}$. The government also taxes consumption at rate $\tau_{C}$, fuel consumed by households at rate $\tau_{M c}$, and fuel used in firm production at rate $\tau_{M_{P}}$. In addition, the government collects a tax on capital $t_{K}$. The total tax revenue is given by

$$
\begin{aligned}
& \operatorname{Tax}=\overbrace{\left(\tau_{L}+\tau_{S S}^{P}\right) \sum_{\theta_{P}} \sum_{j=1}^{J_{1}} w_{P} h_{j}\left(\theta_{P}\right) \mu_{j}\left(\theta_{P}\right)}^{\text {labor and soc. sec. income tax from the private sector }} \\
& \text { labor and soc. sec. income tax from the public sector } \\
& +\overbrace{\left(\tau_{L}+\tau_{S S}^{G}\right) \sum_{\theta_{G}} \sum_{j=1}^{J_{1}} w_{G} h_{j}\left(\theta_{G}\right) \mu_{j}\left(\theta_{G}\right)} \\
& +\overbrace{\tau_{B e q} \sum_{\theta} \sum_{j=1}^{J} a_{j}(\theta) v_{j}(\theta)}^{\text {tax on bequests }} \\
& +\overbrace{\tau_{K} \times(q-\delta) K}^{\text {capital tax }}+\overbrace{\tau_{K} \times r \times B}^{\text {consumption tax }} \text { tax on bonds' interest } \\
& +\overbrace{\tau_{C} \sum_{\theta} \sum_{j=1}^{J} c_{j}(\theta) \mu_{j}(\theta)} \\
& \text { fuel tax/subsidy from } \mathrm{HH} \\
& +\overbrace{\tau_{M_{c}} \sum_{\theta} \sum_{j=1}^{J} \bar{p}_{M} m_{C, j}(\theta) \mu_{j}(\theta)}
\end{aligned}
$$
fuel tax/subsidy from firms

$$
+\overbrace{\tau_{M_{P}} \sum_{\theta} \sum_{j=1}^{J} \bar{p}_{M} m_{P, j}(\theta) \mu_{j}(\theta)},
$$

where $\bar{p}_{M}$ is the world market price of fuel and $q$ is the cost of capital. The government can borrow a fraction $\Delta_{B, t}$ of GDP each period $t$. These bonds are denoted $B_{t+1}=$ $\Delta_{B, t} Y_{t}$, where $\Delta_{B, t}$ is set exogenously. Newly issued bonds have to be detrended with the exogenous technological growth rate $g$ and the exogenous population growth rate $n .^{2}$ The government also collects all profits from the energy sector, EProfit. The government budget constraint can be expressed as

$$
R_{t} B_{t}+C_{G, t}+I_{G, t}+I_{E, t}+\text { Wage }_{G, t}+\text { Pen }_{P, t}+\text { Pen }_{G, t}=\text { Tax }_{t}+(1+g)(1+n) B_{t+1}+\text { EProfit }_{t} .
$$

\footnotetext{
${ }^{2}$ Fuster, Imrohoroglu and Imrohoroglu (2005) use similar exogenous growth rates.
} 


\subsection{Household problem}

In general, households in the private and the government sector have similar maximization problems. Households decide their consumption of final goods and energy as well as leisure $\left\{c_{j}(\theta), l_{j}(\theta), m_{C, j}(\theta)\right\}_{j=1}^{J}$ as a function of their income type and their sector of employment as summarized in state vector $\theta$. The household problem can be recursively formulated as

$$
\begin{aligned}
& V\left(a_{j}(\theta), \theta\right)= \\
& \max _{\left\{a_{j}(\theta), c_{j}(\theta), m_{C, j}(\theta), l_{j}(\theta)\right\}}\left\{u\left(c_{j}(\theta), l_{j}(\theta), m_{c, m}(\theta)\right)+\beta \pi_{j} V^{\prime}\left(a_{j+1}(\theta), \theta\right)\right\} \\
& \text { s.t. } \\
& \left\{\begin{array}{cc}
\left(1+\tau_{C}\right) c_{j}(\theta)+\left(1+\tau_{M_{c}}\right) \bar{p}_{M} m_{C, j}(\theta)+(1+g) a_{j+1}(\theta) & \text { if } j \leq J_{1}, \\
=R a_{j}(\theta)+\left(1-\tau_{L}-\tau_{S S}\right)\left(1-l_{j}(\theta)\right) e_{j}(\theta) w_{t}+\left(1-\tau_{B e q}\right) T_{B e q} & \\
\left(1+\tau_{C}\right) c_{j}(\theta)+\left(1+\tau_{M_{c}}\right) \bar{p}_{M} m_{C, j}(\theta)+(1+g) a_{j+1+1}(\theta) & \text { if } J_{1}<j, \\
=R a_{j}(\theta)+\left(1-\tau_{B e q}\right) T_{B e q}+\operatorname{Pen}_{j}(\theta) &
\end{array}\right. \\
& 0 \leq a_{j}(\theta) \\
& 0<l_{j}(\theta) \leq 1
\end{aligned}
$$

where $j=\{1,2, \ldots, J\}, w_{t}=\left\{w_{P}\right.$ or $\left.w_{G}\right\}$ is the individual wage rate which is sector specific, and $T_{B e q}$ are transfers of accidental bequests that are taxed at rate $\tau_{B e q}$. Notice that household assets are required to be non negative, i.e. households are not allowed to borrow.

\subsection{Firm problems}

Capital and energy can be bought at world market at prices $\bar{q}=\bar{q}_{P}=\bar{q}_{M}$ and $\bar{p}_{M}$ respectively. The final goods producing firm solves the problem

$$
\max _{\left(H_{P}, K_{P}, M_{p}\right)}\left\{F_{P}\left(G_{t}, K_{P}, H_{P}, M_{P}\right)-\bar{q}_{P} K_{P}-w_{P} H_{P}-\left(1+\tau_{M_{P}}\right) \bar{p}_{M} M_{P}\right\}
$$

given $\left(w_{P}, \bar{q}_{P}, \bar{p}_{M}, G\right)$. The fuel producing firm solves the problem

$$
\max _{\left(K_{M}, H_{M}\right)}\left\{\bar{p}_{M} F_{M}\left(K_{M}, H_{M}\right)-\bar{q}_{M} K_{M}-w_{M} H_{M}\right\}
$$

given $\left(\bar{p}_{M}, \bar{q}_{M}, w_{M}\right)$. We graphically summarize the main features of the model in figure 3. 


\subsection{Definition of equilibrium}

We model all markets as competitive so that all households and firms take all prices as given. Given the government policy

$$
\left\{\tau_{L, t}, \tau_{S S}^{P}, \tau_{S S}^{G}, \tau_{B, t}, \tau_{K, t}, \tau_{M_{c}, t}, \tau_{M_{P}, t}, \Delta_{B, t}, \Delta_{G, t}, \Delta_{C_{G}, t}, \xi_{t}^{W}, \Psi_{P t}, \Psi_{G, t}\right\}_{t=0}^{\infty}
$$

and the exogenously given prices

$$
\left\{\bar{q}_{P, t}, \bar{q}_{M, t}, \bar{p}_{M, t}\right\}_{t=0}^{\infty},
$$

a competitive equilibrium is a collection of sequences of decisions of privately and publicly employed households $\left\{l_{j, t}(\theta), c_{j, t}(\theta), m_{c, j, t}(\theta), a_{j+1, t+1}(\theta)\right\}_{t=0}^{\infty}$, sequences of aggregate stocks of private physical capital and private human capital $\left\{K_{P, t}, K_{M, t}, H_{P, t}, H_{M, t}\right\}_{t=0}^{\infty}$, sequences of aggregate stocks of public physical capital and public human capital $\left\{K_{G, t}, H_{G, t}\right\}_{t=0}^{\infty}$, sequences of factor prices $\left\{w_{P, t}, w_{M, t}, w_{G, t}\right\}_{t=0}^{\infty}$ such that

(i) the sequence $\left\{c_{j, t}(\theta), l_{j, t}(\theta), m_{c, j, t}(\theta), a_{j+1, t+1}(\theta)\right\}_{t=0}^{\infty}$ solves the household maximization problem $(6)$,

(ii) domestic capital demand, wages, domestic fuel prices, and the after tax interest rate are determined by

$$
\begin{aligned}
\bar{q}_{P, t} & =\frac{\partial F_{P}\left(G_{t}, K_{P, t}, H_{P, t}, M_{P, t}\right)}{\partial K_{P, t}}, \\
w_{P, t} & =\frac{\partial F_{P}\left(G_{t}, K_{P, t}, H_{P, t}, M_{P, t}\right)}{\partial H_{P, t}}, \\
\bar{q}_{M, t} & =\frac{\bar{p}_{M, t} \partial F_{M}\left(K_{M, t}, H_{M, t}\right)}{\partial K_{M, t}} \\
w_{M, t} & =\frac{p_{M, t} \partial F_{M}\left(K_{M, t} H_{M, t}\right)}{\partial H_{M, t}}, \\
w_{M, t} & =w_{P, t}, \\
w_{G, t} & =\xi^{W} w_{P, t}, \\
\bar{q} & =\bar{q}_{P, t}=\bar{q}_{M, t}, \\
R_{t} & =1+\left(1-\tau_{K, t}\right)\left(\bar{q}_{t}-\delta\right)=1+\left(1-\tau_{K, t}\right) \bar{r}_{t},
\end{aligned}
$$


(iii) aggregate variables are given by

$$
\begin{aligned}
& A_{t}=\sum_{\theta} \sum_{j=1}^{J} a_{j, t}(\theta) \mu_{j, t}(\theta)+\overbrace{\sum_{\theta} \sum_{j=1}^{J} a_{j, t}(\theta) v_{j, t}(\theta)}^{\text {accidental bequests }}, \\
& \text { domestic capital supply domestic capital demand }
\end{aligned}
$$

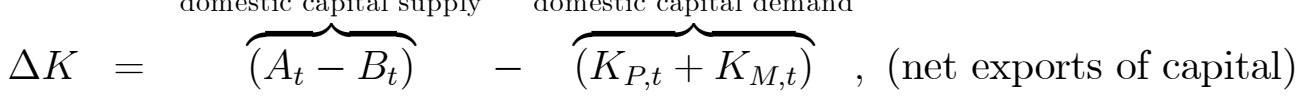

$$
\begin{aligned}
& \bar{p}_{M, t} \Delta M=\bar{p}_{M, t}(\overbrace{F_{M}\left(K_{M, t}\right)}^{\text {domestic energy supply }}-\overbrace{\left(M_{c}+M_{p}\right)}^{\text {domestic energy demand }})>0, \text { (net exports of energy) } \\
& H_{t}=H_{P, t}+H_{M, t}=\sum_{\theta_{P}} \sum_{j=1}^{J} \overbrace{\left(1-l_{j, t}\left(\theta_{P}\right)\right) e_{j, t}\left(\theta_{P}\right)}^{h_{j, t}\left(\theta_{P}\right)} \mu_{j, t}\left(\theta_{P}\right), \\
& H_{t}^{G}=\sum_{\theta_{G}} \sum_{j=1}^{J_{1}} \overbrace{\left(1-l_{j, t}\left(\theta_{G}\right)\right) e_{j, t}\left(\theta_{G}\right)}^{h_{j, t}\left(\theta_{G}\right)} \mu_{j, t}\left(\theta_{G}\right) \\
& S_{t}=\sum_{\theta} \sum_{j=1}^{J} a_{j+1, t+1}(\theta) \mu_{j, t}(\theta), \\
& C_{t}=\sum_{\theta} \sum_{j=1}^{J} c_{j, t}(\theta) \mu_{j, t}(\theta) \text {, } \\
& M_{c, t}=\sum_{\theta} \sum_{j=1}^{J} m_{c, j, t}(\theta) \mu_{j, t}(\theta) \text {, }
\end{aligned}
$$

(iv) commodity markets clear ${ }^{3}$

$$
C_{t}+(1+g) S_{t}+I_{G, t}+C_{G, t}=Y_{t}+\left(1-\delta_{P}\right) K_{t}+(1+n)(1+g) B_{t}+\text { Beq }+ \text { EProfit },
$$

(v) taxed accidental bequests are returned in lump sum transfers to surviving agents

$$
T_{B, t}=\frac{\sum_{\theta_{P}} \sum_{j=1}^{J} a_{j, t}\left(\theta_{P}\right) v_{j, t}\left(\theta_{P}\right)+\sum_{\theta_{G}} \sum_{j=1}^{J} a_{j, t}\left(\theta_{G}\right) v_{j, t}\left(\theta_{G}\right)}{\sum_{\theta} \sum_{j=1}^{J} \mu_{j, t}(\theta)},
$$

(vi) and the government budget constraint (5) holds.

${ }^{3}$ Since the public good $G$ is an input into private sector production of $Y$, the public sector wage bill is already contained in the measure of $Y$. For simplicity we do not take net exports into account when expressing policy parameters as percentage of GDP.

In addition, the aggregate $S_{t}$ already incorporates the exogenous population growth rates via the population weight $\mu$. We therefore only have to detrend with the exogenous technological growth rate $g$. 


\section{Calibration}

We solve the model for steady states using a numerical algorithm similar to Auerbach and Kotlikoff (1987). This algorithm solves a complicated set of non-linear equations using an iterative technique commonly referred to as the Gauss-Seidl method. The algorithm starts with a guess of various endogenous variables and treats them as exogenous. Then, after solving all household and firm maximization problems and imposing the budget constraints and market clearing conditions, the algorithm solves for a new set of endogenous variables. If the new set of endogenous variables equals the original guesses, a solution to the system has been found and the algorithm stops. Otherwise, we take linear combinations of the guessed variables and the new solutions for the variables and start all over. Once the algorithm converges to a steady state, we compare the model's outcome to moments in the data for Egypt. We use a similar algorithm to solve for transitions between two equilibrium allocations that result from changes in policy variables. We check for uniqueness of equilibrium by trying various starting points for the algorithm. ${ }^{4}$

We first calibrate a closed economy version to get prices for energy and capital. We then fix these prices and adjust the total factor productivity of the energy sector to match energy export and capital import figures from Egypt in 2008. We present the parameter values that are used in the baseline model in table 1 . Policy parameters are summarized in table 2 and matched data moments are presented in table 3 . We next describe briefly how we calibrated the model.

\section{$3.1 \quad$ Heterogeneity}

We calibrate the OLG model with $J=14$ periods to Egyptian data. Thus, each model period corresponds to 5 years. Agents become economically active at age 20 and die for sure at age 90 . We differentiate among two income types (rich and poor) and two sector types (private and public), which is summarized in state vector

$$
\theta=\{\text { income }=\{\text { low }, \text { high }\}, \text { sector }=\{\text { Private }, \text { Government }\}
$$

\subsection{Demographics}

We use population fractions by age group from the African Statistical Yearbook (2005). The annual population growth rate was $n=1.8$ percent in 2006 according to the United

\footnotetext{
${ }^{4}$ There is no formal proof of uniqueness available for this type of Auerbach-Kotlikoff models (see Kotlikoff, Smetters and Walliser (2001)). Laitner (1984) provides a proof of uniqueness for a linearized version of the original Auerbach-Kotlikoff model.

Our solution algorithm is locally stable. That is for changes in initial conditions (guesses of initial prices $\mathrm{R}$ and $\mathrm{w}$ ) the algorithm converges to the same steady state. We have no proof of global convergence. It has been our experience that higher order dynamics in multi period OLG models with bonds can lead to multiple steady states. In such cases we were able to rule out Pareto inferior steady states (e.g. steady states that result in negative interest rates). Compare also Colucci (2003) who shows the existence of at least two steady states in a very simple multi period OLG model.
} 
Nations World Population Prospects. ${ }^{5}$ We then choose the survival probabilities so that the model matches the size of the different age groups.

\subsection{Human capital}

Income profiles are calculated using

$$
w h_{j}(\theta)=w \times e_{j}(\theta) \times\left(1-l_{j}(\theta)\right) .
$$

We distinguish between low and high skilled workers, where we define high skilled workers as workers with a post-secondary degree or a university degree. We pick the profiles $e_{j}(\theta)$ so that high skilled agents earn wage incomes that are twice as high as wage incomes of low skilled agents. The efficiency profile exhibits the typical hump-shaped pattern over the life cycle.

According to Worldbank (2008) the skill decomposition in the public sector is 70 percent low skilled workers (i.e. highest degree is vocational high school) and 30 percent high skilled workers (i.e. post-secondary and university and above). The skill decomposition in Egypt overall is roughly 50 percent low skilled and 50 percent high skilled according to Worldbank (2009). Given the size of the public sector, the private sector skill decomposition results in 43 percent low skilled and 57 percent high skilled workers.

In addition we assume that public sector workers are 20 percent less productive on average across both skill groups. However, the public sector income-age profile is higher reflecting the more generous compensation (wages and pensions) in the public sector.

\subsection{Preferences and technology}

Preferences are represented by the following utility function:

$$
u\left(c_{j}(\theta), l_{j}(\theta), m_{C, j}(\theta)\right)=\frac{\left(\Theta \times\left(c_{j}(\theta)^{\gamma} l_{j}(\theta)^{1-\gamma}\right)^{\rho}+(1-\Theta) \times \varrho \times\left(m_{C, j}(\theta)\right)^{\rho}\right)^{\frac{1-\sigma}{\rho}}}{1-\sigma},
$$

where $c$ and $l$ is consumption and leisure respectively and $m_{C}$ is energy consumed by the household, and $0<\gamma<1, \sigma>0,0<\Theta, \varrho<1$, and $\rho>0$. Parameter $\gamma$ measures the relative weight of consumption versus leisure. The elasticity of substitution between consumption and leisure on the one hand and energy $m_{c}$ is $\frac{1}{1-\rho}$. Parameter $\Theta$ measures the importance of consumption and leisure relative to energy. Parameter $\varrho$ is a scale factor that determines the importance of energy consumption, and $\sigma$ is the coefficient of relative risk aversion. Parameter $\Theta=0.96$ and $\varrho=0.2$, both are chosen the primarily match the household demand for energy.

\footnotetext{
${ }^{5}$ Awad and Zohry (2005) find that the population growth rate was about 1.9 percent for the earlier period from 1990 to 2005.
} 
The elasticity of substitution between consumption and energy is $\frac{1}{1-\rho}=0.8$ so that $\rho=-0.25$. Consumption and energy are therefore complements. The consumption preference parameter $\gamma=0.28$ is chosen to get labor supply to be around $30-35$ hours a week for agents in their prime working age from 25 to 55 . Both, the time preference parameter $\beta=1.022$ and the inverse of the intertemporal elasticity of substitution $\sigma=2.2$ are chosen to match the capital output ratio. ${ }^{6}$ Consequently, in our model the resulting capital output ratio is equal to 2.9 .

Final goods production. The production function for the final good is

$$
F_{P}\left(G, K_{P}, H_{P}, M_{P}\right)=A_{1} G^{\alpha_{1}} K_{P}^{\alpha_{2}} H_{P}^{\alpha_{3}} M_{P}^{\alpha_{4}}
$$

where $\alpha_{i} \in(0,1)$ for $i=1, \ldots, 4, \alpha_{2}+\alpha_{3}+\alpha_{4}=1$ and $A_{1}>0$. Total factor productivity $A_{1}$ is normalized to one. The exogenous technological rate of growth is 1 percent (Worldbank communication). The estimates for $\alpha_{1}$, the productivity parameter of the public good in the final goods production function, for the U.S. cluster around 0 when panel data techniques are used (e.g. Hulten and Schwab (1991) and Holtz-Eakin (1994)) and they cluster around 0.2 when GMM is used to estimate Euler equations (e.g. Lynde and Richmond (1993) and Ai and Cassou (1995)). Calderon and Serven (2003) estimate this parameter to be around 0.15 and 0.20 . For a cross-section of low income countries Hulten (1996) obtains an estimate for $\alpha_{1}$ of 0.10 . We use $\alpha_{1}=0.09$, which is a conservative estimate in order to not overstate our results.

The capital share of GDP is relatively high in Egypt so we chose $\alpha_{2}=0.52$. Since this is a small open economy model where capital and energy can be traded at world market prices, the model also results in capital imports of 7.4 percent of GDP. Worldbank sources report estimates that range between 5.46 to 6.6 percent of GDP on average between 2005 to 2008 . We set the capital depreciation rate to 10 percent per year. Parameter $\alpha_{3}=0.39$ together with the preference parameter for leisure $(1-\gamma)$ determines average hours worked. We pick $\alpha_{4}$, the share of energy in production to be equal 0.08 . We chose this parameter to match the size of the energy sector in Egypt. The size of the energy production sector is jointly determined by parameters $\alpha_{4}$ (domestic industry demand for energy), $\Theta$ (household demand for energy), and $A_{2}$ (energy supply) which we describe next.

Energy production. The energy production function is

$$
F_{M}\left(K_{M}, H_{M}\right)=A_{2} K_{M}^{\eta_{21}} H_{M}^{\eta_{22}}
$$

where $A_{2}>0$ and $\eta_{21}, \eta_{22}, \in(0,1)$ and $\eta_{21}+\eta_{22} \leq 1$. If the production function exhibits constant returns to scale this will result in zero profits. If we have decreasing returns

\footnotetext{
${ }^{6}$ It is clear that in a general equilibrium model every parameter affects all equilibrium variables. Here we associate parameters with those equilibrium variables that they affect the most directly quantitatively.
} 
to scale, profits $\pi_{M}$ will be redistributed to the government. We chose $\eta_{21}=0.66$ and $\eta_{22}=0.12$ so that firms make a profit of 4.6 percent of GDP. According to the Worldbank profits from the energy sector are around 3 percent (Worldbank communication). In the model all profits from the energy sector are collected by the government. Total factor productivity $A_{2}$ is chosen to match the size of the energy sector and also the size of energy exports. In the model, energy exports amount to 5.4 percent of GDP compared to empirical estimates between 5.8 percent of GDP (Worldbank communication).

Public good production. The production function for the public good is

$$
F_{G}\left(K_{G}, H_{G}\right)=A_{3} K_{G}^{\eta_{3}}\left(\omega_{h} H_{G}\right)^{\left(1-\eta_{3}\right)}
$$

where $A_{3}>0$ and $\eta_{3} \in(0,1)$. The fraction of civil servants contributing to the production of the public good is denoted $\omega_{h} \in(0,1)$. The remaining civil servants produce government consumption that is not explicitly modeled. Total factor productivity $A_{3}=1.05$ is chosen to match the size of the public goods sector. We have little information about the parameters of the production technology of the public good. We view the choice of $\eta_{3}=0.6$ and $\omega_{h}=0.4$ as our benchmark and we perform sensitivity analysis on these parameters. We find that our qualitative and quantitative results are relatively robust to changes in $\eta_{3}$ and $\omega_{h}$. Capital $K_{G}$ depreciates at 10 percent per year.

\subsection{Labor markets and government}

Labor markets. In the model we assume that all agents retire at age 60 , or $J_{1}=8$. The total number of periods in a life is $J=14$ which corresponds to age 90 . The government policy parameters are summarized in table 2 .

Government expenditures. Based on Worldbank (2009) public sector employment as fraction of total employment is approximately 25 percent. In addition, public sector workers earn on average up to 10 percent higher wages than private sector workers. Since this number is calculated factoring in income of informal sector workers, we pick a slightly more moderate markup factor of public wages of 5 percent so that $\xi^{W}=1.05$ to not overstate wages in the public sector.

According to Gupta et al. (2009), 90 percent of the labor force is covered by the pension program. In order to not overstate the replacement rates in the private sector we decided to match the size of the pension programs (public and private) as percent of GDP as well as the government revenue from payroll taxes paying for pensions. ${ }^{7}$

\footnotetext{
${ }^{7}$ Pension replacement rates in the public sector are 80 percent on average. Replacement rates in the private sector are higher. Estimates for replacement rates are as high as 150 percent of average lifetime salary (see Gupta et al. (2009)). These high replacement rates in the private sector are the result of averaging. There are large groups of workers working in the private sector who have very low income and some of these workers are informal sector workers. However, we do not distinguish informal vs. formal sector workers in our model. The private sector replacement rates in our model are therefore much lower and chosen to match aggregate private sector pension payments.
} 
This allows us to not only match the size of pension programs but also their relative deficit/surplus. In 2007 the pension system in Egypt ran a deficit of 0.8 percent of GDP according to Gupta et al. (2009), where the private sector pensions contributed a deficit of 0.9 percent of GDP and public sector pension plans ran a surplus of roughly 0.1 percent of GDP. We therefore end up using replacement rates of $\Psi_{P}=0.35$ and $\Psi_{P}=0.99$ as well as payroll taxes of $\tau_{S S}^{P}=2.8$ percent and $\tau_{S S}^{G}=16.6$ percent. ${ }^{8}$

Government income. In addition the government raises labor taxes, consumption taxes, taxes on bequests, and taxes on profits (in the model this is approximated using capital taxes ${ }^{9}$ ) to finance public sector workers, government consumption, investments into public capital, and service of its debt. Capital taxes in Egypt are zero. However, tax revenues raised from corporate profits are three times the size of revenues raised from labor income taxes. If one excludes taxes collected from Suez Canal profits, the tax revenue raised on company profits is still twice the size of labor income tax revenue. In our model we use capital taxes as a proxy for taxes on profits and choose the capital tax rate so that revenue streams from taxes on profits are matched.

We set the tax rates so that revenue streams from the various taxes are matched to data from Worldbank (2009). Table 3 presents the details. According to Worldbank (2009) total tax and non-tax revenues as fraction of GDP are about 28 percent, half from personal and corporate income tax, the remainder from sales and excise taxes. This revenue figure includes profits from oil exports and Suez canal fees so that estimates for tax revenue itself are probably between 15 and 20 percent. The model is calibrated to generate tax revenues of 22.3 percent of GDP.

The size of the energy subsidies is 5.29 percent of GDP according to Worldbank (2009). We choose subsidy rates for households of $\tau_{M_{C}}=30$ percent and $\tau_{M_{P}}=30$ percent which result in energy subsidies of 4.6 percent in the model.

The government issues new bonds in the amount of $\Delta_{B}=12$ percent of GDP in every model period which results in a steady state government debt level of 65 percent of GDP (Worldbank (2009) states 65 percent as well).

We calibrate investments into a public capital that is needed to produce a public good (e.g. roads etc.) to be $\Delta_{G}=2$ percent of GDP in order to match the size of the public good production as a share of GDP (27 percent according to Worldbank (2009). In our model the government share in production is 29.2 percent of GDP, 8.4 percent from public goods production (produced by a public capital and public sector workers) and 20.7 percent from energy production (produced by physical capital and human capital employed in the energy sector at competitive wages). Profits from the energy sector are redistributed to the government.

\footnotetext{
${ }^{8}$ The statutory contribution rates are between $21-24$ percent for salaried employees and between $14-16$ percent for workers (Worldbank (2009)).

${ }^{9}$ Capital taxes in the model are raised on asset returns of households and not on capital stock in the production sector.
} 


\section{Policy experiments and results}

In our experiment we decrease the energy price subsidy by 15 percent and let either consumption taxes $\left(\tau_{C}\right)$, labor taxes $\left(\tau_{L}\right)$, capital/profit taxes $\left(\tau_{K}\right)$, or investments into the public capital $\left(\Delta_{G}\right)$ adjust to clear the government budget constraint in reaction to the simulated 15 percent change of the respective status quo variable. The policy changes are unanticipated by all agents and result in either decreases of $\tau_{C}, \tau_{L}$, and $\tau_{K}$ or increases of infrastructure investments $\Delta_{G}$.

\subsection{Decrease in energy subsidies for both consumers and pro- ducers}

Energy is heavily subsidized in Egypt and the total energy subsidy amounts to roughly 5.29 percent of GDP. In this section we simulate a decrease in the subsidy rate by 15 percent. Steady state results are presented in table 4 . The first column in table 4 is the normalized benchmark regime before the policy change. We normalized all level variables to 100 to allow for simple comparisons between the pre-reform equilibrium and the new post-reform equilibrium after reform has become fully effective.

Since energy subsidies drop, the government responds with either tax decreases or increases in infrastructure investments. See column two for post reform steady state results with an adjustment of labor taxes $\tau_{L}$, column three for post-reform steady state results with an adjustment in consumption taxes $\tau_{C}$, column four for post-reform steady state results with an adjustment in capital tax rates $\tau_{K}$, and column five for post-reform steady state results when infrastructure investments $\Delta_{G}$ adjust to accommodate the drop in energy subsidies.

Steady state analysis with an adjustment in labor taxes. A drop in the subsidy rate increases both, the price of energy used for the production of final goods and services as well as the price of energy consumed by households. This cut does not have much of an effect on the domestic production of energy though, as energy can always be traded at fixed world market prices, so that the value of domestic energy production $p_{M} M$ stays relatively stable. However, labor taxes can now adjust downwards from 5 to 2.9 percent to accommodate the decrease in energy subsidies. This generates an income effect that triggers various changes in a household's consumption and savings portfolio.

First, we observe an increase in domestic capital accumulation $K$ of 2.3 percent due to income effects (see second column in table 4). This increase in domestic capital accumulation allows Egypt to decrease its imports of physical capital by 18 percent as now more domestically accumulated capital (via household savings) becomes available. The drop in the labor tax rate provides a direct source of extra income to working households so that they can increase their consumption level $C$ by 1.2 percent.

Despite the lower tax rates, growth effects of output cannot be realized. The reason

is that Egypt is a small open economy that has access to international capital markets. 
Since physical capital $K_{P}$ and energy $M_{P}$ are complements in the production function for the final consumption good, cutting the energy subsidies causes a decrease in the return for physical capital, so that physical capital used in domestic production $K_{P}$ decreases by about 1.1 percent. This allows for a decrease of physical capital imports by 18 percent. All in all domestic output of final goods and services drops by about 1.1 percent.

Transition dynamics with an adjustment in labor taxes. Figure 4 depicts the transition paths for a select number of market aggregates. We see that after an initial jump, most variables converge to the new steady state in a smooth manner. The lower labor taxes directly generate additional income for working households which translates into higher consumption of the numeraire good $C$ (panel 7, in figure 4). Household energy consumption, on the other hand, drops immediately due to the cuts in subsidies (panel 8, in figure 4). Whether this results in welfare gains or welfare losses depends on the relative importance of the final consumption good $C$ and household energy consumption of $M_{c}$ in the households' preferences but also on the extra income generated for each households. Since in this case labor taxes can be lowered after the government cuts its expenditures on subsidies, working households will gain directly from this reform. Retired households, on the other hand, will not be able to obtain any additional tax breaks.

We provide the following welfare measures over the transition path in figure 5 . Panel [1] expresses welfare gains/losses in terms of compensating consumption units that are expressed as a fixed percentage of life-time consumption. We provide these measures for each generation separately. Generation 0 is the first generation born right after the reform has been implemented. Generations to the left of zero were born up to 13 periods before the reform and generations to the right of zero are born after the reform. Compensating consumption units are given to households born in the new steady state in order to make them indifferent between the pre-reform equilibrium and the post-reform equilibrium. Negative values in this graph indicate welfare gains, positive values are welfare losses.

Comparing the welfare graphs in figure 5 we immediately see that retired households will not gain from the reform, whereas working households are identified as winners from the reform. Generation zero roughly gains 0.5 percent of consumption in each of its 14 life periods. In other words, if we took away half a percent of period consumption in each period from generation zero, then generation zero would be indifferent (in terms of utility) between the pre-reform and post-reform steady states. We see that the retired generation does not gain at all, the working generation before the reform starts to have welfare gains up to 0.5 percent of consumption, whereas generations born about 15 periods after the reform can fully benefit from the lower tax rate and realize gains of almost 1 percent of per period consumption. There is not any significant difference between the low and high income groups in terms of welfare gains. The second panel shows an almost identical situation for public sector workers. This makes sense as public sector workers are not treated any different by the reform.

Finally, we would like to measure welfare gains for each period after the reform, 
aggregated over all generations that are alive in said period. We express the aggregate compensating consumption units of all alive generations per period as a fraction of GDP in that period to give a better indication about the size of the overall welfare effect. We find that the small welfare losses of the retired generations are more than compensated by welfare gains of the working generations, so that the reform creates an immediate aggregate welfare gain at the end of the period of its implementation. These welfare gains start growing to about 0.6 percent of GDP as the economy sets into the new equilibrium.

Steady state analysis with an adjustment in consumption taxes. We next let consumption taxes adjust (decrease) to accommodate the drop in energy subsidies and find that consumption taxes decrease from roughly 16.6 percent to 14.7 percent (column 3 in table 4). The first difference to the previous experiment is that now all generations can benefit from lower taxes, not just the working generations. This has a direct impact on the welfare results, which we will discuss shortly.

The lower consumption tax triggers a strong substitution effect, so that households switch their consumption from energy $p_{M} M_{C}$ to the final consumption good $C$. We find that aggregate consumption $C$ increases by 0.6 percent. Similarly, we find that household consumption of energy $p_{M} M_{C}$ drops by almost 6 percent. Because domestic demand for energy decreases, more energy is now exported at the fixed world market price. As energy use in domestic production $M_{p}$ decreases by over 7 percent (column three in table 4 ), energy exports increase by 21 percent to roughly 6.6 percent of GDP(up from 5.4).

Simultaneously, the domestic production sector of final goods and services experiences a drop in output of almost 2 percent of GDP as it now uses less energy. Negative income effects from decreases in output also affect the savings rate of the households, so that physical capital accumulation decreases and steady state capital $K$ drops by more 1 percent. The economy therefore increases its imports of physical capital by 1.4 percent.

Transition dynamics with an adjustment in consumption taxes. The transition dynamics point to welfare increases that stem from increases in consumption $C$ of the final good (see figure 6 for transition results of market aggregates and figure 7 for welfare results). This extra consumption is made possible by cuts in the sales tax but also by increases in energy exports. It is apparent that these welfare gains are realized for both, working and retired generations, contrary to the earlier result derived from a labor tax adjustment. The compensating consumption that can be achieved in the long run is around 0.3 percent of per period consumption for private and public sector workers. The welfare gains, in terms of percent increases, are slightly larger for the high income group. Welfare gains expressed as fraction of GDP are around 0.2 percent and therefore much smaller than in the previous experiment.

In terms of implementability of these reforms, it will obviously be easier to find a majority of voters for the second reform (using consumption taxes) as the intergenerational conflict can be avoided. 
Steady state analysis with an adjustment in capital taxes. Capital taxes decrease from 15 percent to 7.2 percent as they accommodate the subsidy cuts. We observe the largest effect on capital accumulation in this case as the after tax return to capital is directly increased. We find that steady state capital $K$ increases by 10.6 percent (see fourth column in table 4). Egypt therefore decreases its current capital import by almost 77 percent. In addition, less energy is used in the production process due to the lack of the subsidies so that output drops significantly. The additional capital that was accumulated by households is used to decrease the imports but does not increase the level of physical capital used in the domestic production process. This level, $K_{P}$, actually drops slightly. Despite the drop in output $Y$, aggregate consumption $C$ again increases.

Steady state analysis with an adjustment in investment in public capital. Lower energy subsidies leave funds for infrastructure investments, assuming that the government holds tax rates at their pre-reform levels. Infrastructure investments can therefore increase from 2 to 2.7 percent of GDP (see column five in table 4).

The extra infrastructure investments increase the production of the public good $G$ by 22.5 percent. Since $G$ enters the final goods production function, the marginal returns to physical capital inputs $K_{P}$ increase, so that the domestically used level of physical capital increases by 2.76 percent. Returns to energy used in the production of the final good would equally increase, however, the factor energy itself has now become more expensive, so that overall less energy is used in domestic production, i.e. $p_{M} M_{P}$ decreases by 3.5 percent. All these effects combined will increase GDP by 2.5 percent. The additional income generated allows households to consume more final consumption goods and services ( $C$ increases by 2.5 percent).

\subsection{Sensitivity analysis}

\subsubsection{Decrease in energy subsidies of various sizes}

Labor tax case. We next implement cuts of energy subsidies of various sizes and let either labor taxes or infrastructure investments adjust to clear the government budget constraint. Table 5 reports the results for a decrease in the labor tax and table 6 contains similar results for increases in infrastructure investments. The cuts in energy subsidies are again implemented for both, consumers and producers. The first column shows again normalized, pre-reform steady state aggregates. Column 2 to 7 report steady state results for energy cuts of $25,30,45,60,75$, and 90 percent.

From table 5 we see that the results for market aggregates are monotone when gradually cutting energy subsidies by 15 percent up to 90 . The most severe cut of 90 percent decreases steady state output $Y$ by 5.5 percent, despite a 10 percent increase in domestic capital accumulation $K$ (savings). Cutting subsidies to such a large extent allows Egypt to almost double its energy exports (92.3 percent increase). Aggregate consumption 
levels do rise by up to 4.8 percent.

Infrastructure investments. Table 6 indicates that infrastructure investments can be increased from 2 to 5.8 percent. This increase is also responsible for a 7 percent increase in the domestic savings rate. Despite the fact that energy usage in the final goods production decreases by almost 33 percent, the additional physical capital in production $K_{P}$, as well as the additionally available public good ( $G$ almost doubles) will increase output by 7.6 percent. This is the largest output gain that we found in any of the experiments (see column 7 in table 6). Finally, steady state consumption levels $C$ increase by 6.8 percent.

\subsubsection{Decrease in energy subsidies for consumers vs. producers}

We next analyze the difference in cutting the subsidy for consumers vs. producers. If we cut energy subsidies to households by 15 percent and leave the energy subsidies for firms in place, we find that energy consumption of households $p_{M} M_{C}$ decreases by up to 4.4 percent whereas energy consumption of producers $p_{M} M_{P}$ stays stable. Table 7 reports the results when we let either consumption taxes $\left(\tau_{C}\right)$, labor taxes $\left(\tau_{L}\right)$, capital/profit taxes $\left(\tau_{K}\right)$, or investments into the public capital $\left(\Delta_{G}\right)$ adjust to clear the government budget. Column one is the benchmark economy normalized to 100 when the respective variable is a level variable. The effects are typically smaller than in table 4 where subsidies to both firms and households are cut simultaneously.

We next cut energy subsidies to firms by 15 percent and leave the energy subsidies for households in place. Table 8 reports the steady state results for this case. Column one is again the benchmark economy normalized to 100 when the respective variable is a level variable. In this case we find the opposite effect on the energy consumption patterns. Household consumption of energy $p_{M} M_{C}$ remains relatively stable, since household subsidies remain in place, whereas energy usage by firms $p_{M} M_{P}$ decreases by up to 8.4 percent.

In terms of output we immediately see that 15 percent cuts in energy subsidies to producers will decrease steady state output by up to 2.4 percent, whereas a similar cut of energy subsidies to households will barely decrease output. In addition, we find that cuts to energy subsidies for producers allow for more drastic adjustments in the policy variables (i.e. taxes or infrastructure investments) which in turn will trigger larger substitution and income effects. The welfare effects are larger in the case of cuts to energy subsidies for producers, as in this case consumers are able to maintain their

level of consumption of energy in addition to the increase of consumption levels of the final good. 


\section{Conclusion}

We have constructed a dynamic general equilibrium model, calibrated it to Egypt and used it to study the effects of a decrease of energy subsidies. The overall findings that emerge from this analysis are: a 15 percent reduction of energy subsidies to households and firms can either lead to decreases of GDP by 3 percent or increases of GDP by a similar amount. The expansionary or contractionary effect is mainly determined by the government policy that reacts to the subsidy cut and clears the. If infrastructure investments are increased after the subsidy cut, then growth effects can be realized. If subsidy cuts are handed back to households via lower taxes, no such growth effects will result as households simply consume the extra income and excess energy is exported at fixed world market prices. More severe cuts of energy subsidies amplify all effects monotonically.

Overall we find that welfare gains for most generations along the transition path can be realized. Only in the case with lower labor taxes in reaction to the subsidy cuts do we observe welfare losses by generations that are already retired when the reform takes place. These cohorts are not able to benefit from the lower taxes. We also find that energy cuts to producers lead to more direct growth effects. In addition, positive welfare effects are also larger as consumers do not suffer from higher (unsubsidized) energy prices and are therefore able to maintain their prior levels of energy consumption.

There are a few modeling choices we have made. First, we have not modeled explicitly the international trade side and the question of how these fiscal policy reforms would influence the trade balance. We have abstracted from explicitly modeling the formal and informal sector. These policy reforms undoubtedly would impact workers in the informal sector differentially since they would be excluded from pension benefits but also from some forms of taxation.

\section{References}

African Statistical Yearbook. 2005. African Development Bank Group, African Union, and Economic Commission for Africa.

Ai, Chunrong and Stephen P. Cassou. 1995. "A Normative Analysis of Public Capital." Applied Economics 27:1201-1209.

Auerbach, J. Alan and Laurence J. Kotlikoff. 1987. Dynamic Fiscal Policy. Cambridge University Press.

Awad, Alyaa and Ayman Zohry. 2005. "The End of Egypt Population Growth in the 21st Century: Challenges and Aspirations." Cairo Demographic Center.

Baier, Scott and Gerhard Glomm. 2001. "Long-Run Growth and Welfare Effects of Public Policies." Journal of Economic Dynamics and Control 25(12):2007-2042. 
Barro, Robert J. 1990. "Government Spending in a Simple Model of Endogenous Growth." Journal of Political Economy 98(5):S103-S125.

Blankenau, William F. and Nicole B. Simpson. 2004. "Public Education Expenditures and Growth." Journal of Development Economics 73:583-605.

Brock, William and M. Taylor. 2010. "The Green Solow Model." Journal of Economic Growth 15(2):127-153.

Calderon, Cesar and Luis Serven. 2003. The Limits of Stabilization: Infrastructure, Public Deficits, and Growth in Latin America. Stanford University Press and the World Bank chapter The Output Cost of Latin America's Infrastructure Gap.

Colucci, Domenico. 2003. "Steady States in the OLG Model with Seignorage and LongLived Agents." Research in Economics 57:371-381.

Fuster, Luisa, Ayse Imrohoroglu and Selahattin Imrohoroglu. 2005. "Personal Security Accounts and Mandatory Annuitization in a Dynastic Framework." CESIfo Working Paper No. 1405.

Glomm, Gerhard and B. Ravikumar. 1997. "Productive government expenditures and long-run growth." Journal of Economic Dynamics and Control 21(1):183-204.

Glomm, Gerhard and B. Ravikumar. 1998. "Flat-Rate Taxes, Government Spending on Education, and Growth." Review of Economic Dynamics 1(1):306-325.

Glomm, Gerhard, D. Kawaguchi and F. Sepulveda. 2008. "Green taxes and double dividends in a dynamic economy, 30 (2008), pp. 1932." Journal of Policy Modeling 30:19-32.

Gupta, Sanjeev, Robert Gillingham, Adam Leive, Anita Tuladhar, George Schieber and Tatyana Bogomolova. 2009. "Arab Republic of Egypt: Fiscal Implications of Pension and Health Care Reform." International Monetary Fund, Fiscal Affairs Department.

Holtz-Eakin, Douglas. 1994. "Public Sector Capital and the Productivity Puzzle." Review of Economics and Statistics 76(1):12-21.

Huggett, Mark. 1996. "Wealth Distribution in Life-Cycle Economies." Journal of Monetary Economics 38:469-494.

Hulten, Charles B. 1996. "Infrastructure Capital and Economic Growth: How well you use it may be moreimortantthan how much you have." NBER Working Paper No. 5847 .

Hulten, Charles B. and Robert M. Schwab. 1991. "Public Capital Formation and the Growth of Regional Manufacturing Industries." National Tax Journal Proceedings of a Conference on the Tax-Exempt Bond Market:121-134. 
IEA. 2010a. "Analysis of the scope of energy subsidies and suggestions for the G-20 initiative." IEA, OPEC, OECD, WORLD BANK.

IEA. 2010b. "Energy Subsidies: Getting the Prices Right." IEA Office of the chief economist.

IEA. 2010c. "World Energy Outlook 2010.".

Kotlikoff, Laurence J., Kent Smetters and Jan Walliser. 2001. "Finding a Way Out of America's Demographic Dilemma." NBER Working Paper No. 8258.

Laitner, John. 1984. "Transition Time Paths for Overlapping-Generations Models." Journal of Economic Dynamics and Control 7(2):111-129.

Lucas, Robert E., Jr. 1990. "Supply-Side Economics: An Analytical Review." Oxford Economic Papers 42(2):293-316.

Lynde, Cahterince and James Richmond. 1993. "Public Capital and Total Factor Productivity." International Economic Review 34:401-414.

Moon, YS and YH Sonn. 1996. "Productive energy consumption and economic growth: An endogenous growth model and its empirical applications." Resource and Energy Economics 18:189-200.

Pereira, Alfredo M. and Rui M. Pereira. 2011a. "Marginal Abatement Cost Curves and the Budgetary Impact of CO2 Taxation in Portugal." College of William and Mary Economics, Working Paper 105.

Pereira, Alfredo M. and Rui M. Pereira. 2011b. "On the Environmental, Economic and Budgetary Impacts of Fossil Fuel Prices: A Dynamic General Equilibrium Analysis of the Portuguese Case." College of William and Mary Economics, Working Paper 110.

Peretto, P.F. 2009. "Energy Taxes and Endogenous Technological Change." Environmental Economics and Management 57(3):269-283.

Plante, Michael. 2011. "The Long-run Macroeconomic Impacts of Fuel Subsidies in an Oil-importing Developing Country." Federal Reserve Bank of Dallas.

Saint-Paul, Gilles. 1992. "Fiscal Policy in an Endogenous Growth Model." The Quarterly Journal of Economics 107(4):1243-1259.

Smulders, Sjak and Michiel de Nooij. 2003. "The impact of energy conservation on technology and economic growth." Resource and Energy Economics 25(1):59-79.

Turnovsky, Stephen J. 1999. "Productive Government Expenditure in a Stochastically Growing Economy." Macroeconomic Dynamics 3:544-540. 
Turnovsky, Stephen J. 2000. "Fiscal Policy, Elastic Labor Supply, and Endogenous Growth." Journal of Monetary Economics 45:185-210.

Worldbank. 2008. Arab Republic of Egypt: Egypt: Government Employment and Wage Policy. The World Bank.

Worldbank. 2009. Arab Republic of Egypt Transforming Egypt: A Development Policy Review. The World Bank. 


\section{Appendix}

\subsection{Tables and Figures}

\begin{tabular}{|c|c|c|}
\hline Parameters & Model: & Observation/Source: \\
\hline \multicolumn{3}{|l|}{ Preferences } \\
\hline Discount factor & $\beta=1.022$ & To match $\frac{K}{Y}$ and $R$ \\
\hline Inverse of intertemp. elast. of subst. & $\sigma=2.2$ & To match $\frac{K}{Y}$ and $R$ \\
\hline Weight on consumption & $\gamma=0.28$ & To match average hours worked. \\
\hline Weight on $c$ and $l$ & $\Theta=0.96$ & \\
\hline Weight on $m_{C}$ & $\varrho=0.2$ & \\
\hline $\begin{array}{l}\text { Elasticity of substitution } \\
\text { between } c \text { and } m_{C} \text { is } \frac{1}{1-\rho}\end{array}$ & $\rho=-0.25$ & $c$ and $m_{C}$ are complements \\
\hline \multicolumn{3}{|l|}{ Private Production: } \\
\hline TFP & $A_{1}=1$ & Normalization \\
\hline Productivity of public good $G$ & $\alpha_{1}=0.09$ & \\
\hline Capital productivity & $\alpha_{2}=0.39$ & Worldbank communication \\
\hline Human capital productivity & $\alpha_{3}=0.53$ & \\
\hline Intermediate good productivity & $\alpha_{4}=0.08$ & \\
\hline Capital depreciation & $\delta=10 \%$ & \\
\hline Long run growth rate & $g=1 \%$ & Worldbank communication \\
\hline \multicolumn{3}{|l|}{ Intermediate Good Production: } \\
\hline \multirow[t]{3}{*}{ TFP for intermediate good } & $A_{2}=0.8$ & To match size of Energy sector \\
\hline & $\eta_{21}=0.66$ & Positive profit in energy sector \\
\hline & $\eta_{22}=0.12$ & Match size of energy sector workforce \\
\hline \multicolumn{3}{|l|}{ Public Production: } \\
\hline \multirow[t]{2}{*}{ TFP for public good production } & $A_{3}=1.05$ & To match public sector size \\
\hline & $\eta_{3}=0.6$ & Sensitivity analysis \\
\hline Productive civil servants & $\omega_{h}=40 \%$ & Sensitivity analysis \\
\hline Public capital depreciation & $\delta_{G}=10 \%$ & To match public sector size \\
\hline \multicolumn{3}{|l|}{ Human Capital: } \\
\hline Efficiency profile & $e_{j}(\theta)$ & $\begin{array}{l}\text { To match size of } \\
\text { public good sector and hours worked }\end{array}$ \\
\hline Efficiency profile low vs. high skilled & $2: 1$ & \\
\hline Distribution low vs. high skilled, public & $70 \% / 30 \%$ & Worldbank (2008) \\
\hline population growth rate & $n=1.8 \%$ & UN World Population Prospects \\
\hline
\end{tabular}

Table 1: Model parameters 


\begin{tabular}{|c|c|c|}
\hline & Model: & Observation/Source: \\
\hline $\begin{array}{l}\text { Labor Allocation: } \\
\text { fraction of civil servants } \\
\text { private sector employees }\end{array}$ & $\begin{array}{l}N^{G}=25 \% \\
N^{P}=75 \%\end{array}$ & $\begin{array}{l}\text { Worldbank (2009) } \\
\text { Worldbank (2009) }\end{array}$ \\
\hline \multicolumn{3}{|l|}{ Expenditures: } \\
\hline $\begin{array}{l}\text { Public wages markup } \\
\text { Replacement rates } \\
\text { (generosity of pensions) }\end{array}$ & $\begin{array}{l}\xi^{W}=1.05 \\
\Psi_{P}=35 \% \\
\Psi_{G}=99 \%\end{array}$ & $\begin{array}{l}\text { Worldbank }(2009) \\
\text { to match pension sizes }\end{array}$ \\
\hline $\begin{array}{l}\text { Investment in public good } \\
\text { (in } \% \text { of private sector output) }\end{array}$ & $\Delta_{G}=2 \%$ & Worldbank communication \\
\hline $\begin{array}{l}\text { Residual gov't consumption } \\
\text { (in } \% \text { of private sector output) }\end{array}$ & $\Delta_{C_{G}}=0 \%$ & $\begin{array}{l}\text { Residual (thrown into ocean), } \\
\text { to match labor tax revenue }\end{array}$ \\
\hline $\begin{array}{l}\text { Government bonds } \\
\text { (in } \% \text { of private sector output) }\end{array}$ & $\Delta_{B}=12 \%$ & $\begin{array}{l}\text { To match debt level of } 65 \% \\
\text { of GDP, Worldbank communication }\end{array}$ \\
\hline \multicolumn{3}{|l|}{ Taxes: } \\
\hline Labor tax rate; private & $\tau_{L}^{P}=5 \%$ & Adjusts endogenously \\
\hline Labor tax rate; public & $\tau_{L}^{G}=5 \%$ & Adjusts endogenously \\
\hline Consumption tax rate & $\tau_{C}=16.6 \%$ & $\begin{array}{l}\text { To match consumption tax } \\
\text { share in tax revenue }\end{array}$ \\
\hline Capital/profit tax rate & $\tau_{K}=15 \%$ & $\begin{array}{l}\text { To match capital/profit tax } \\
\text { share in tax revenue }\end{array}$ \\
\hline Energy tax $\mathrm{HH}$ & $\tau_{M_{C}}=-30 \%$ & To match subsidy, $5.39 \%$ of GDP \\
\hline Energy tax firms & $\tau_{M_{P}}=-30 \%$ & To match subsidy, $5.39 \%$ of GDP \\
\hline Tax on bequests & $\tau_{B e q}=20 \%$ & To match tax revenue of labor tax \\
\hline Social security tax-private & $\tau_{S S}^{P}=2.8 \%$ & To match pension deficit $-0.9 \%$ of GDP \\
\hline Social security tax-public & $\tau_{S S}^{G}=16.6 \%$ & To match pension deficit $+0.1 \%$ of GDP \\
\hline
\end{tabular}

Table 2: Policy parameters 


\begin{tabular}{|c|c|c|c|}
\hline Moments & Model: & Data: & Observation/Source: \\
\hline Capital output ratio: $\frac{K}{Y}$ & 2.9 & 3.1 & Worldbank communication \\
\hline Annual interest rate: $r$ & $5.0 \%$ & $3 \%$ & Worldbank communication \\
\hline $\begin{array}{l}\text { Public sector share } \\
\text { of GDP: } \frac{G+\bar{p}_{M} M}{Y}\end{array}$ & $29.2 \%$ & $27 \%$ & $\begin{array}{l}\text { Worldbank communication, } 17 \% \\
\text { from energy, } 10 \% \text { from } \\
\text { public good. }\end{array}$ \\
\hline Hours worked/week: & 34.9 & $30-35$ & Worldbank communication \\
\hline Hours worked/week, private: & 35.7 & $30-35$ & Worldbank communication \\
\hline Hours worked/week, public: & 32.5 & $30-35$ & Worldbank communication \\
\hline Public good production: $\frac{G}{Y}$ & $8.4 \%$ & $10 \%$ & Worldbank communication \\
\hline Energy prod. in $\%$ of GDP & $20.7 \%$ & $17 \%$ & Worldbank (2009) \\
\hline Energy profits in $\%$ of GDP & $4.6 \%$ & $3 \%$ & Worldbank communication \\
\hline Energy exports in \% of GDP & $5.4 \%$ & $5.8 \%$ & Worldbank communication \\
\hline Capital imports in \% of GDP & $-7.4 \%$ & $-5.4-6.6 \%$ & $\begin{array}{l}\text { Worldbank communication } \\
\text { average in past } 3 \text { years }\end{array}$ \\
\hline \multicolumn{4}{|l|}{$\begin{array}{l}\text { Government Size: } \\
\text { (all in } \% \text { of GDP) }\end{array}$} \\
\hline Total tax revenue & $22.3 \%$ & $15-20 \%$ & $\begin{array}{l}\text { Worldbank ( } 2009) \\
25 \% \text { from income, } 25 \% \text { from profits, } \\
50 \% \text { from sales/excise taxes }\end{array}$ \\
\hline Energy subsidy & $4.6 \%$ & $5.29 \%$ & Worldbank (2009) \\
\hline Labor tax revenue & $3.3 \%$ & $1.7 \%$ & Worldbank (2009) \\
\hline Consumption tax revenue & $9.8 \%$ & $7.5 \%$ & Worldbank (2009) \\
\hline Capital/profit tax revenue & $3.6 \%$ & $3.4 \%$ & Worldbank (2009) \\
\hline Soc.Sec.Rev.:private sector & $1.5 \%$ & $1.1 \%$ & Gupta et al. (2009) \\
\hline Soc.Sec.Rev.:public sector & $1.6 \%$ & $1.6 \%$ & Gupta et al. (2009) \\
\hline Bequest tax revenue & $2.5 \%$ & $N / A$ & to match size of tax revenue \\
\hline \multicolumn{4}{|l|}{$\begin{array}{l}\text { Expenditures: } \\
\text { (all in \% of GDP) }\end{array}$} \\
\hline Wage bill public sector & $12.0 \%$ & $8 \%$ & Worldbank (2009) \\
\hline Private pensions & $2.3 \%$ & $2 \%$ & Gupta et al. (2009) \\
\hline Public pension & $1.5 \%$ & $1.5 \%$ & Gupta et al. (2009) \\
\hline Debt & $65 \%$ & $65 \%$ & Worldbank (2009) \\
\hline \multicolumn{4}{|l|}{$\begin{array}{l}\text { Pension Deficit: } \\
\text { (all in } \% \text { of GDP) }\end{array}$} \\
\hline Total pension deficit & $-0.7 \%$ & $-0.8 \%$ & Gupta et al. (2009) \\
\hline Pension balance priv. sector & $-0.8 \%$ & $-0.9 \%$ & Gupta et al. (2009) \\
\hline Pension balance pub. sector & $+0.1 \%$ & $+0.1 \%$ & Gupta et al. (2009) \\
\hline
\end{tabular}

Table 3: Model generated moments that match Egyptian data 


\begin{tabular}{|c|c|c|c|c|c|}
\hline & Benchmark & $\tau_{L}$ & $\tau_{C}$ & $\tau_{K}$ & $\Delta_{G}$ \\
\hline GDP & 100.000 & 98.808 & 98.697 & 96.878 & 102.513 \\
\hline Output $Y$ & 100.000 & 98.933 & 98.899 & 96.915 & 102.760 \\
\hline Capital $K$ & 100.000 & 102.332 & 99.002 & 110.595 & 102.542 \\
\hline Capital in fuel $K_{M}$ & 100.000 & 100.573 & 100.586 & 100.751 & 98.642 \\
\hline Capital in final $K_{P}$ & 100.000 & 98.933 & 98.899 & 96.915 & 102.760 \\
\hline Human capital private $H_{P}$ & 100.000 & 100.053 & 100.044 & 98.435 & 100.027 \\
\hline Human capital public $H_{G}$ & 100.000 & 100.215 & 100.050 & 98.425 & 100.031 \\
\hline Public good $G$ & 100.000 & 99.368 & 99.236 & 97.494 & 122.513 \\
\hline Consumption $C$ & 100.000 & 101.176 & 100.564 & 101.124 & 102.524 \\
\hline Energy production $p_{M} * M$ & 100.000 & 100.573 & 100.586 & 100.751 & 98.642 \\
\hline Energy consumption $p_{M} * M_{C}$ & 100.000 & 96.099 & 94.336 & 96.097 & 97.188 \\
\hline Energy used in prod. $p_{M} * M_{P}$ & 100.000 & 92.957 & 92.926 & 91.061 & 96.553 \\
\hline Exp: Capital (imp. if neg.) & -100.000 & -82.056 & -101.405 & -23.890 & -96.450 \\
\hline Exp: Energy (imp. if neg.) & 100.000 & 119.664 & 121.228 & 124.189 & 104.059 \\
\hline Energy Profit & 100.000 & 100.573 & 100.586 & 100.751 & 98.642 \\
\hline Wages $w$ & 100.000 & 98.957 & 98.935 & 98.638 & 102.539 \\
\hline After tax interest rate $r$ in $\%$ & 5.096 & 5.096 & 5.096 & 5.096 & 5.096 \\
\hline Labor $\operatorname{tax} \tau_{L}$ in $\%$ & 5.005 & 2.956 & 5.000 & 5.000 & 5.000 \\
\hline Consumption tax $\tau_{C}$ in $\%$ & 16.563 & 16.563 & 14.652 & 16.563 & 16.563 \\
\hline Capital tax $\tau_{K}$ in $\%$ & 15.000 & 15.000 & 15.000 & 7.224 & 15.000 \\
\hline Infrastruc. Inv. $\Delta_{G}$ in $\%$ & 2.000 & 2.000 & 2.000 & 2.000 & 2.733 \\
\hline Energy subsidy & 100.000 & 79.785 & 79.333 & 78.638 & 82.226 \\
\hline$K / G D P$ & 2.936 & 3.040 & 2.945 & 3.351 & 2.937 \\
\hline Energy production/GDP in $\%$ & 20.756 & 21.127 & 21.153 & 21.585 & 19.975 \\
\hline Cap. exp./GDP (imp.if neg.) \% & -7.435 & -6.174 & -7.636 & -1.834 & -6.994 \\
\hline Energy exp./GDP (imp.if neg.) \% & 5.397 & 6.536 & 6.629 & 6.918 & 5.482 \\
\hline Energy profits/GDP in $\%$ & 6.986 & 7.111 & 7.120 & 7.266 & 6.724 \\
\hline Energy susidies/GDP in \% & 4.608 & 3.721 & 3.704 & 3.740 & 3.696 \\
\hline Debt to GDP ratio in $\%$ & 64.997 & 64.997 & 64.997 & 64.997 & 64.997 \\
\hline Hours worked: & 34.929 & 34.944 & 34.947 & 34.462 & 34.940 \\
\hline Hours worked private & 35.734 & 35.736 & 35.752 & 35.260 & 35.745 \\
\hline Hours worked public & 32.516 & 32.567 & 32.534 & 32.067 & 32.527 \\
\hline
\end{tabular}

Table 4: Experiment: Decrease energy subsidies for both, households and producers by $15 \%$. Column one presents the benchmark economy. We then let consumption taxes (column 2), labor taxes (column 3), capital taxes (column 4), or infrastructure investments (column 5) adjust to clear the government budget constraint. 


\begin{tabular}{|c|c|c|c|c|c|c|c|}
\hline & Benchmark & $\tau_{L}: 15$ & $\tau_{L}: 30$ & $\tau_{L}: 45$ & $\tau_{L}: 60$ & $\tau_{L}: 75$ & $\tau_{L}: 90$ \\
\hline GDP & 100.000 & 98.808 & 97.693 & 96.648 & 95.666 & 94.740 & 93.866 \\
\hline Output $Y$ & 100.000 & 98.933 & 97.935 & 96.998 & 96.117 & 95.285 & 94.499 \\
\hline Capital $K$ & 100.000 & 102.332 & 104.385 & 106.174 & 107.743 & 109.127 & 110.350 \\
\hline Capital in fuel $K_{M}$ & 100.000 & 100.573 & 101.117 & 101.633 & 102.126 & 102.596 & 103.047 \\
\hline Capital in final $K_{P}$ & 100.000 & 98.933 & 97.935 & 96.998 & 96.117 & 95.285 & 94.499 \\
\hline Human capital private $H_{P}$ & 100.000 & 100.053 & 100.102 & 100.147 & 100.189 & 100.229 & 100.267 \\
\hline Human capital publ & 100.000 & 100.215 & 100.404 & 100.573 & 100.725 & 100.863 & 100.989 \\
\hline Public good $G$ & 100.000 & 99.368 & 98.768 & 98.199 & 97.658 & 97.144 & 96.653 \\
\hline Consumption $C$ & 100.000 & 101.176 & 102.178 & 103.026 & 103.746 & 104.360 & 104.882 \\
\hline Energ & 100.000 & 100.573 & 101.117 & 101.633 & 102.126 & 102.596 & 103.047 \\
\hline Ener & 100.000 & 96.099 & 92.475 & 89.097 & 85.946 & 83.004 & 30.253 \\
\hline Energy used in prod. $p_{1}$ & 100.000 & 92.957 & 86.778 & 81.316 & 76.457 & 72.108 & 68.195 \\
\hline Exp: Capital & -100.000 & -82.056 & -66.032 & -51.816 & -39.116 & -27.711 & -17.437 \\
\hline Exp: Energ & 100.000 & 19.664 & 137.240 & 153.058 & 167.376 & 180.404 & 192.317 \\
\hline Energy Profit & 100.000 & 100.573 & 101.117 & 101.633 & 102.126 & 102.596 & 103.047 \\
\hline Wages & 100.000 & 98.957 & 97.984 & 97.073 & 96.217 & 95.410 & 94.647 \\
\hline After tax interest rat & 5.096 & 5.096 & 5.096 & 5.096 & 5.096 & 5.096 & 5.096 \\
\hline Labor tax $\tau_{L}$ in $\%$ & 5.005 & 2.956 & 1.093 & $\begin{array}{c}-0.602 \\
\end{array}$ & -2.153 & -3.579 & -4.894 \\
\hline $\operatorname{tax} \tau_{C}$ in $\%$ & 16.563 & 16.563 & 16.563 & 16.563 & 16.563 & 16.563 & 16.563 \\
\hline Capit & 15.000 & 15.000 & 15.000 & 15.000 & 15.000 & 15.000 & 15.000 \\
\hline Infrastruc. Inv. $\Delta_{G} \mathrm{i}$ & 2.000 & 2.000 & 2.000 & 2.000 & 2.000 & 2.000 & 2.000 \\
\hline Energy subsidy & 100.000 & 79.785 & 61.897 & 45.960 & 31.679 & 18.814 & 7.168 \\
\hline$K / G D P$ & 2.936 & 3.040 & 3.137 & 3.225 & 3.306 & 3.382 & 3.451 \\
\hline Energy prod & 20.756 & 21.127 & 21.483 & 21.827 & 22.157 & 22.477 & 22.786 \\
\hline Cap. exp./GDP (imp.if neg.) \% & -7.435 & -6.174 & -5.025 & -3.986 & -3.040 & -2.175 & -1.381 \\
\hline Energy exp./GDP (imp.if neg.) \% & 5.397 & 6.536 & 7.582 & 8.547 & 9.442 & 10.277 & 11.057 \\
\hline Energy profits/GI & 6.986 & 7.111 & 7.231 & 7.347 & 7.458 & 7.566 & 7.670 \\
\hline Energy susidies/GDP in \% & 4.608 & 3.721 & 2.919 & 2.191 & 1.526 & 0.915 & 0.352 \\
\hline Debt to GDP ratio in $\%$ & 64.997 & 64.997 & 64.997 & 64.997 & 64.997 & 64.997 & 64.997 \\
\hline Hours worked: & 34.929 & 34.944 & 34.956 & 34.969 & 34.981 & 34.992 & 35.004 \\
\hline Hours worked private & 35.734 & 35.736 & 35.738 & 35.741 & 35.745 & 35.749 & 35.754 \\
\hline Hours worked public & 32.516 & 32.567 & 32.611 & 32.652 & 32.688 & 32.722 & 32.753 \\
\hline
\end{tabular}

Table 5: Experiment: Decrease energy subsidies for both, households and firms by $15 \%, 30 \%, 45 \%, 60 \%, 75 \%$, and $90 \%$. Column one presents the benchmark economy. We then let labor taxes adjust to clear the government budget constraint. 


\begin{tabular}{|c|c|c|c|c|c|c|c|}
\hline & Benchmark & $\Delta_{G}: 15$ & $\Delta_{G}: 30$ & $\Delta_{G}: 45$ & $\Delta_{G}: 60$ & $\Delta_{G}: 75$ & $\Delta_{G}: 90$ \\
\hline GDP & 100.000 & 102.501 & 104.109 & 105.141 & 105.795 & 106.190 & 106.403 \\
\hline Output $Y$ & 100.000 & 102.748 & 104.578 & 105.810 & 106.643 & 107.201 & 107.561 \\
\hline Capital $K$ & 100.000 & 102.539 & 104.239 & 105.384 & 106.161 & 106.680 & 107.016 \\
\hline Capital in fuel $K_{M}$ & 100.000 & 98.647 & 97.780 & 97.213 & 96.840 & 96.597 & 96.446 \\
\hline Capital in final $K_{P}$ & 100.000 & 102.748 & 104.578 & 105.810 & 106.643 & 107.201 & 107.561 \\
\hline Human capital private $H_{P}$ & 100.000 & 100.027 & 100.055 & 100.084 & 100.113 & 100.141 & 100.169 \\
\hline Human capital public $H_{G}$ & 100.000 & 100.032 & 100.063 & 100.096 & 100.129 & 100.161 & 100.193 \\
\hline Public good $G$ & 100.000 & 122.434 & 141.891 & 158.709 & 173.346 & 186.179 & 197.515 \\
\hline Consumption $C$ & 100.000 & 102.519 & 104.177 & 105.277 & 106.006 & 106.478 & 106.768 \\
\hline Energy production $p_{M} * M$ & 100.000 & 98.647 & 97.780 & 97.213 & 96.840 & 96.597 & 96.446 \\
\hline Energy consumption $p_{M} * M_{C}$ & 100.000 & 97.184 & 94.010 & 90.745 & 87.528 & 84.424 & 81.464 \\
\hline Energy used in prod. $p_{M} * M_{P}$ & 100.000 & 96.542 & 92.664 & 88.703 & 84.830 & 81.125 & 77.621 \\
\hline Exp: Capital (imp. if neg.) & -100.000 & -96.416 & -94.040 & -92.463 & -91.407 & -90.712 & -90.274 \\
\hline Exp: Energy (imp. if neg.) & 100.000 & 104.112 & 111.233 & 119.753 & 128.800 & 137.917 & 146.861 \\
\hline Energy Profit & 100.000 & 98.647 & 97.780 & 97.213 & 96.840 & 96.597 & 96.446 \\
\hline Wages $w$ & 100.000 & 102.528 & 104.202 & 105.318 & 106.064 & 106.553 & 106.859 \\
\hline After tax interest rate $r$ in $\%$ & 5.096 & 5.096 & 5.096 & 5.096 & 5.096 & 5.096 & 5.096 \\
\hline Labor $\operatorname{tax} \tau_{L}$ in $\%$ & 5.005 & 5.000 & 5.000 & 5.000 & 5.000 & 5.000 & 5.000 \\
\hline Consumption tax $\tau_{C}$ in $\%$ & 16.563 & 16.563 & 16.563 & 16.563 & 16.563 & 16.563 & 16.563 \\
\hline Capital tax $\tau_{K}$ in $\%$ & 15.000 & 15.000 & 15.000 & 15.000 & 15.000 & 15.000 & 15.000 \\
\hline Infrastruc. Inv. $\Delta_{G}$ in $\%$ & 2.000 & 2.733 & 3.440 & 4.105 & 4.725 & 5.301 & 5.837 \\
\hline Energy subsidy & 100.000 & 82.218 & 65.137 & 49.111 & 34.244 & 20.520 & 7.873 \\
\hline$K / G D P$ & 2.936 & 2.937 & 2.939 & 2.943 & 2.946 & 2.949 & 2.953 \\
\hline Energy production/GDP in \% & 20.756 & 19.975 & 19.494 & 19.191 & 18.999 & 18.881 & 18.814 \\
\hline Cap. exp./GDP (imp.if neg.) \% & -7.435 & -6.994 & -6.716 & -6.538 & -6.424 & -6.351 & -6.308 \\
\hline Energy exp./GDP (imp.if neg.) \% & 5.397 & 5.482 & 5.766 & 6.147 & 6.570 & 7.009 & 7.449 \\
\hline Energy profits/GDP in \% & 6.986 & 6.724 & 6.562 & 6.460 & 6.395 & 6.355 & 6.333 \\
\hline Energy susidies/GDP in \% & 4.608 & 3.696 & 2.883 & 2.152 & 1.491 & 0.890 & 0.341 \\
\hline Debt to GDP ratio in $\%$ & 64.997 & 64.997 & 64.997 & 64.997 & 64.997 & 64.997 & 64.997 \\
\hline Hours worked: & 34.929 & 34.940 & 34.952 & 34.964 & 34.975 & 34.987 & 34.998 \\
\hline Hours worked private & 35.734 & 35.745 & 35.756 & 35.768 & 35.779 & 35.791 & 35.802 \\
\hline Hours worked public & 32.516 & 32.527 & 32.539 & 32.551 & 32.563 & 32.574 & 32.586 \\
\hline
\end{tabular}

Table 6: Experiment: Decrease energy subsidies for both, households and firms by $15 \%, 30 \%, 45 \%, 60 \%, 75 \%$, and $90 \%$. Column one presents the benchmark economy. We then let public infrastructure investments adjust to clear the government budget constraint. 


\begin{tabular}{|c|c|c|c|c|c|}
\hline & Benchmark & $\tau_{L}$ & $\tau_{C}$ & $\tau_{K}$ & $\Delta_{G}$ \\
\hline GDP & 100.000 & 99.834 & 99.804 & 99.417 & 100.879 \\
\hline Output $Y$ & 100.000 & 100.031 & 100.021 & 99.598 & 101.108 \\
\hline Capital $K$ & 100.000 & 100.894 & 100.033 & 102.627 & 101.022 \\
\hline Capital in fuel $K_{M}$ & 100.000 & 100.006 & 100.009 & 100.043 & 99.460 \\
\hline Capital in final $K_{P}$ & 100.000 & 100.031 & 100.021 & 99.598 & 101.108 \\
\hline Human capital private $H_{P}$ & 100.000 & 100.041 & 100.038 & 99.697 & 100.034 \\
\hline Human capital public $H_{G}$ & 100.000 & 100.087 & 100.043 & 99.716 & 100.038 \\
\hline Public good $G$ & 100.000 & 99.935 & 99.899 & 99.536 & 106.017 \\
\hline Consumption $C$ & 100.000 & 100.554 & 100.387 & 100.458 & 100.978 \\
\hline Energy production $p_{M} * M$ & 100.000 & 100.006 & 100.009 & 100.043 & 99.460 \\
\hline Energy consumption $p_{M} * M_{C}$ & 100.000 & 95.588 & 95.128 & 95.519 & 95.932 \\
\hline Energy used in prod. $p_{M} * M_{P}$ & 100.000 & 100.031 & 100.021 & 99.598 & 101.108 \\
\hline Exp: Capital (imp. if neg.) & -100.000 & -94.929 & -99.927 & -82.681 & -98.576 \\
\hline Exp: Energy (imp. if neg.) & 100.000 & 103.588 & 104.000 & 104.665 & 99.027 \\
\hline Energy Profit & 100.000 & 100.006 & 100.009 & 100.043 & 99.460 \\
\hline Wages $w$ & 100.000 & 99.989 & 99.983 & 99.921 & 100.997 \\
\hline After tax interest rate $r$ in $\%$ & 5.096 & 5.096 & 5.096 & 5.096 & 5.096 \\
\hline Labor $\operatorname{tax} \tau_{L}$ in $\%$ & 5.005 & 4.475 & 5.000 & 5.000 & 5.000 \\
\hline Consumption tax $\tau_{C}$ in $\%$ & 16.563 & 16.563 & 16.074 & 16.563 & 16.563 \\
\hline Capital tax $\tau_{K}$ in $\%$ & 15.000 & 15.000 & 15.000 & 13.136 & 15.000 \\
\hline Infrastruc. Inv. $\Delta_{G}$ in $\%$ & 2.000 & 2.000 & 2.000 & 2.000 & 2.183 \\
\hline Energy subsidy & 100.000 & 94.605 & 94.484 & 94.279 & 95.455 \\
\hline$K / G D P$ & 2.936 & 2.967 & 2.943 & 3.030 & 2.940 \\
\hline Energy production/GDP in \% & 20.756 & 20.792 & 20.798 & 20.886 & 20.468 \\
\hline Cap. exp./GDP (imp.if neg.) \% & -7.435 & -7.070 & -7.441 & -6.184 & -7.264 \\
\hline Energy exp./GDP (imp.if neg.) \% & 5.397 & 5.600 & 5.623 & 5.681 & 5.301 \\
\hline Energy profits/GDP in $\%$ & 6.986 & 6.998 & 7.001 & 7.030 & 6.889 \\
\hline Energy susidies/GDP in \% & 4.608 & 4.366 & 4.362 & 4.370 & 4.360 \\
\hline Debt to GDP ratio in $\%$ & 64.997 & 64.997 & 64.997 & 64.997 & 64.997 \\
\hline Hours worked: & 34.929 & 34.944 & 34.945 & 34.847 & 34.943 \\
\hline Hours worked private & 35.734 & 35.745 & 35.749 & 35.648 & 35.747 \\
\hline Hours worked public & 32.516 & 32.540 & 32.531 & 32.443 & 32.530 \\
\hline
\end{tabular}

Table 7: Experiment: Decrease energy subsidies for households only by $15 \%$. Column one presents the benchmark economy. We then let consumption taxes (column 2), labor taxes (column 3), capital taxes (column 4), or infrastructure investments (column 5) adjust to clear the government budget constraint. 


\begin{tabular}{|c|c|c|c|c|c|}
\hline & Benchmark & $\tau_{L}$ & $\tau_{C}$ & $\tau_{K}$ & $\Delta_{G}$ \\
\hline GDP & 100.000 & 98.977 & 98.891 & 97.607 & 101.780 \\
\hline Output $Y$ & 100.000 & 98.904 & 98.879 & 97.472 & 101.796 \\
\hline Capital $K$ & 100.000 & 101.409 & 98.969 & 107.340 & 101.640 \\
\hline Capital in fuel $K_{M}$ & 100.000 & 100.567 & 100.576 & 100.692 & 99.098 \\
\hline Capital in final $K_{P}$ & 100.000 & 98.904 & 98.879 & 97.472 & 101.796 \\
\hline Human capital private $H_{P}$ & 100.000 & 100.014 & 100.006 & 98.865 & 99.994 \\
\hline Human capital public $H_{G}$ & 100.000 & 100.130 & 100.007 & 98.870 & 99.993 \\
\hline Public good $G$ & 100.000 & 99.436 & 99.336 & 98.110 & 116.560 \\
\hline Consumption $C$ & 100.000 & 100.612 & 100.169 & 100.540 & 101.679 \\
\hline Energy production $p_{M} * M$ & 100.000 & 100.567 & 100.576 & 100.692 & 99.098 \\
\hline Energy consumption $p_{M} * M_{C}$ & 100.000 & 100.529 & 99.167 & 100.497 & 101.435 \\
\hline Energy used in prod. $p_{M} * M_{P}$ & 100.000 & 92.930 & 92.906 & 91.585 & 95.647 \\
\hline Exp: Capital (imp. if neg.) & -100.000 & -87.301 & -101.477 & -45.636 & -97.739 \\
\hline Exp: Energy (imp. if neg.) & 100.000 & 116.052 & 117.258 & 119.285 & 104.155 \\
\hline Energy Profit & 100.000 & 100.567 & 100.576 & 100.692 & 99.098 \\
\hline Wages $w$ & 100.000 & 98.969 & 98.952 & 98.743 & 101.676 \\
\hline After tax interest rate $r$ in $\%$ & 5.096 & 5.096 & 5.096 & 5.096 & 5.096 \\
\hline Labor tax $\tau_{L}$ in $\%$ & 5.005 & 3.500 & 5.000 & 5.000 & 5.000 \\
\hline Consumption tax $\tau_{C}$ in $\%$ & 16.563 & 16.563 & 15.147 & 16.563 & 16.563 \\
\hline Capital tax $\tau_{K}$ in $\%$ & 15.000 & 15.000 & 15.000 & 9.296 & 15.000 \\
\hline Infrastruc. Inv. $\Delta_{G}$ in $\%$ & 2.000 & 2.000 & 2.000 & 2.000 & 2.534 \\
\hline Energy subsidy & 100.000 & 85.214 & 84.806 & 84.391 & 87.118 \\
\hline$K / G D P$ & 2.936 & 3.008 & 2.938 & 3.228 & 2.932 \\
\hline Energy production/GDP in $\%$ & 20.756 & 21.089 & 21.109 & 21.412 & 20.212 \\
\hline Cap. exp./GDP (imp.if neg.) \% & -7.435 & -6.558 & -7.626 & -3.477 & -7.138 \\
\hline Energy exp./GDP (imp.if neg.) \% & 5.397 & 6.328 & 6.399 & 6.595 & 5.526 \\
\hline Energy profits/GDP in $\%$ & 6.986 & 7.099 & 7.105 & 7.207 & 6.803 \\
\hline Energy susidies/GDP in \% & 4.608 & 3.967 & 3.951 & 3.984 & 3.944 \\
\hline Debt to GDP ratio in $\%$ & 64.997 & 64.997 & 64.997 & 64.997 & 64.997 \\
\hline Hours worked: & 34.929 & 34.929 & 34.932 & 34.589 & 34.927 \\
\hline Hours worked private & 35.734 & 35.725 & 35.736 & 35.387 & 35.731 \\
\hline Hours worked public & 32.516 & 32.543 & 32.518 & 32.196 & 32.514 \\
\hline
\end{tabular}

Table 8: Experiment: Decrease energy subsidies for producers only by $15 \%$. Column one presents the benchmark economy. We then let consumption taxes (column 2), labor taxes (column 3), capital taxes (column 4), or infrastructure investments (column 5) adjust to clear the government budget constraint. 


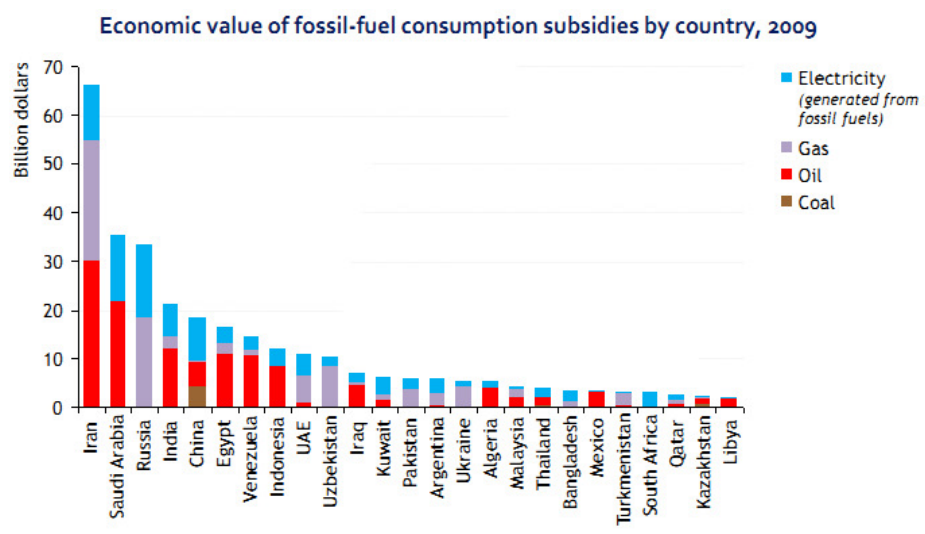

Figure 1: Taken from World Energy Outlook 2010, a publication of the IEA.

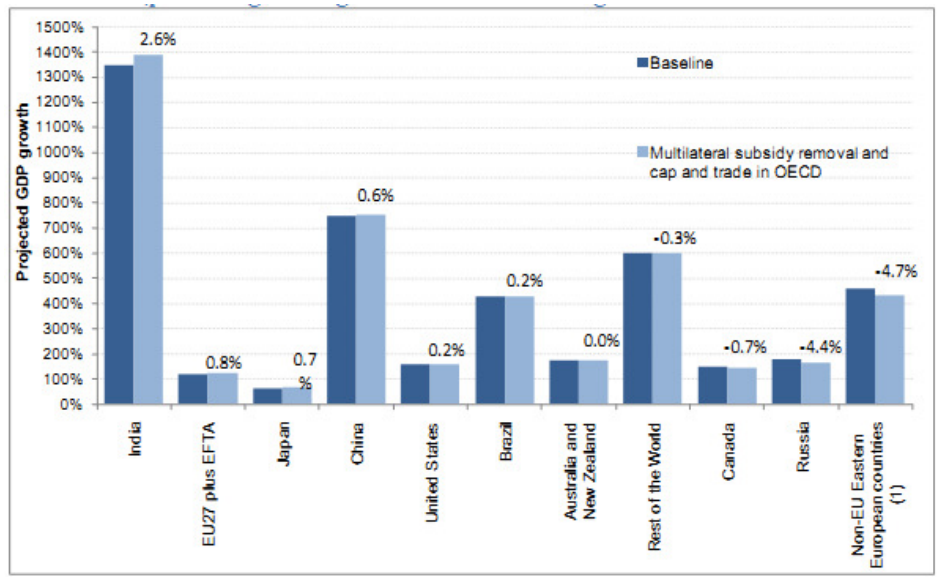

Figure 2: Long term impact on GDP of a multilateral phasing out of fossil-fuel subsidies by regions in 2050 (percentage changes indicate GDP change in 2050 relative to the baseline) - Figure taken from IEA (2010a), page 27. 


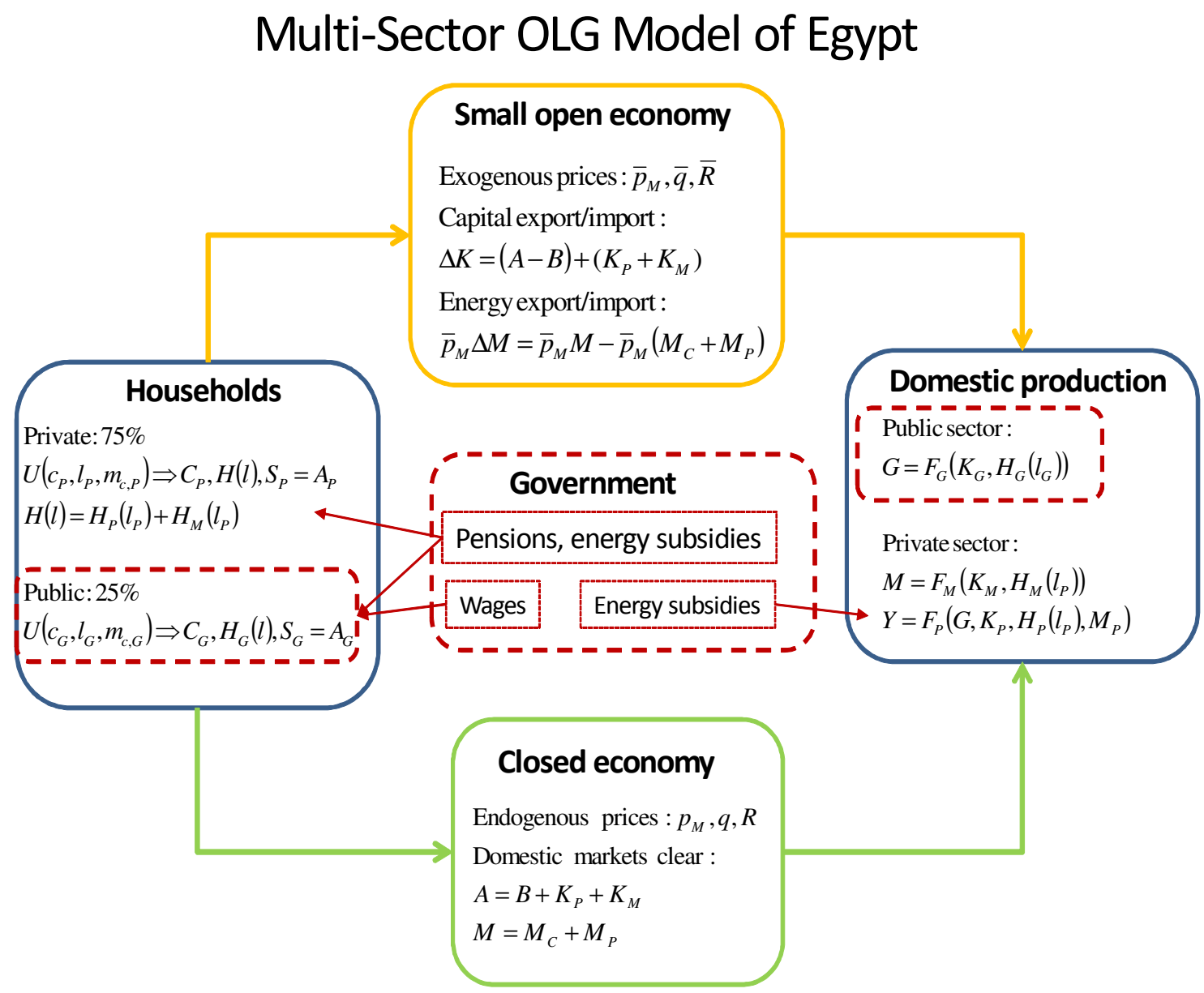

Figure 3: Multi sector OLG model of Egypt. 

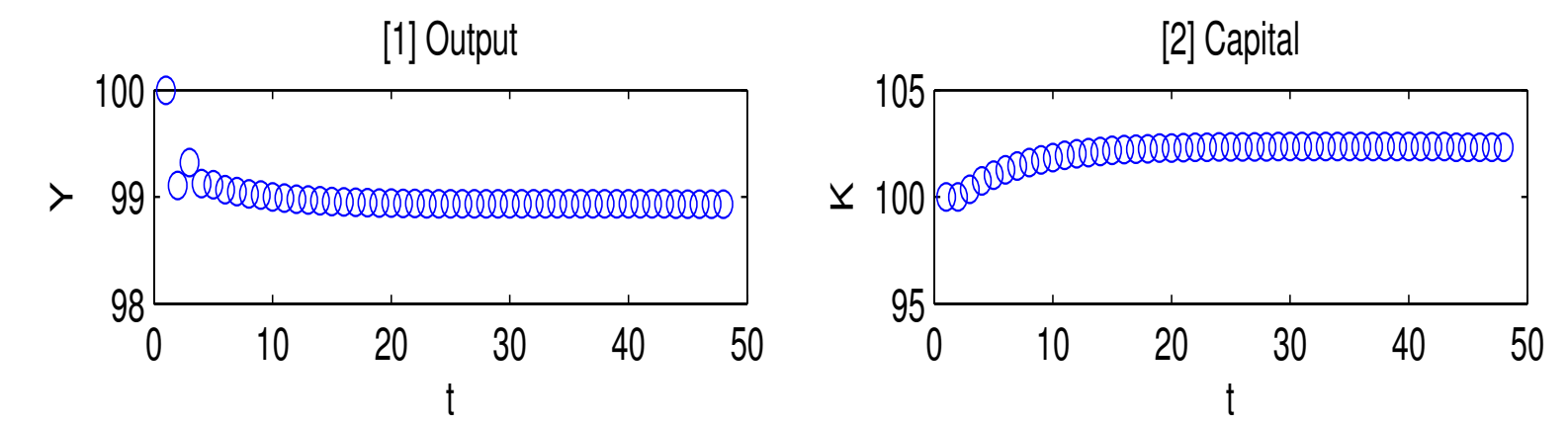

[3] Wages
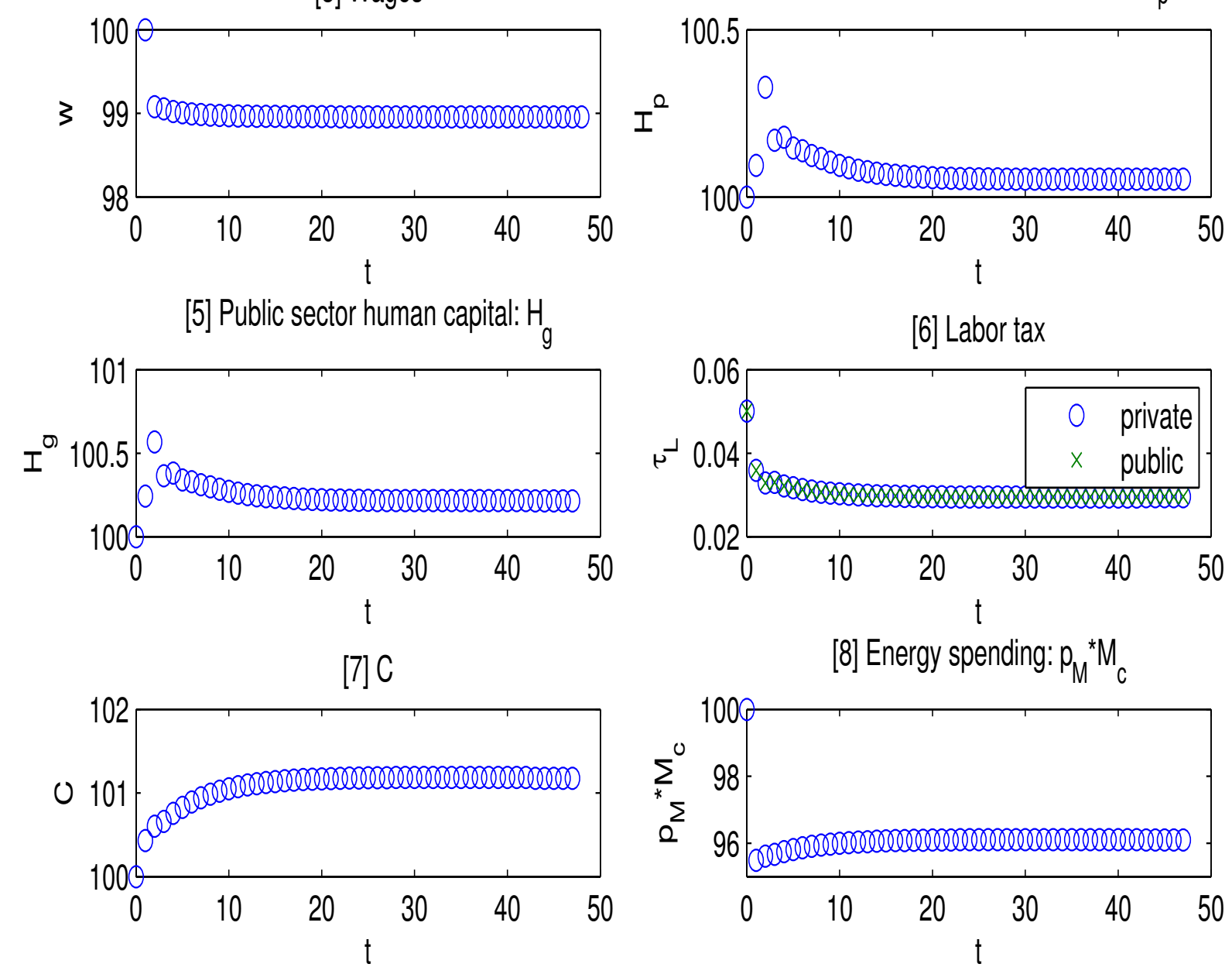

Figure 4: Transitions: Decrease energy subsidies for both, households and producers by $15 \%$ and let labor taxes adjust to accommodate the drop in energy subsidies. 


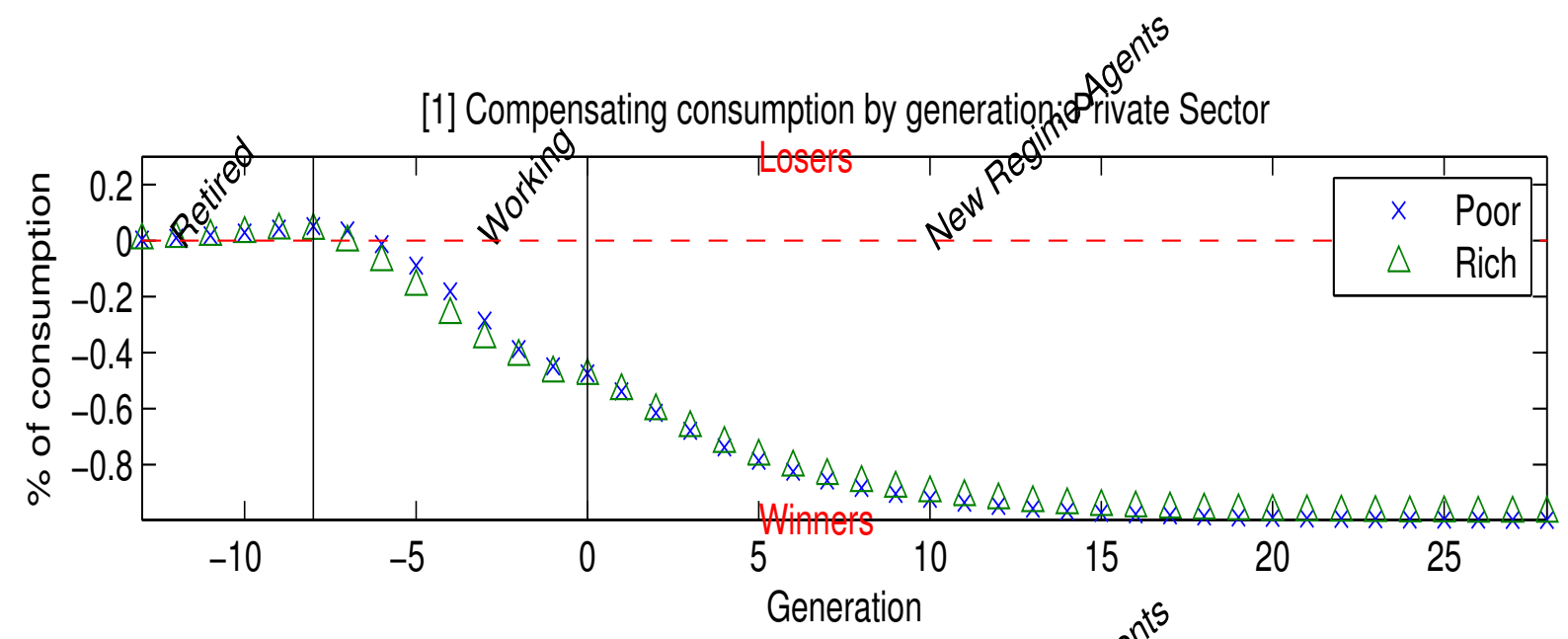

[2] Compensating consumption by generation: Ragsfic Sector

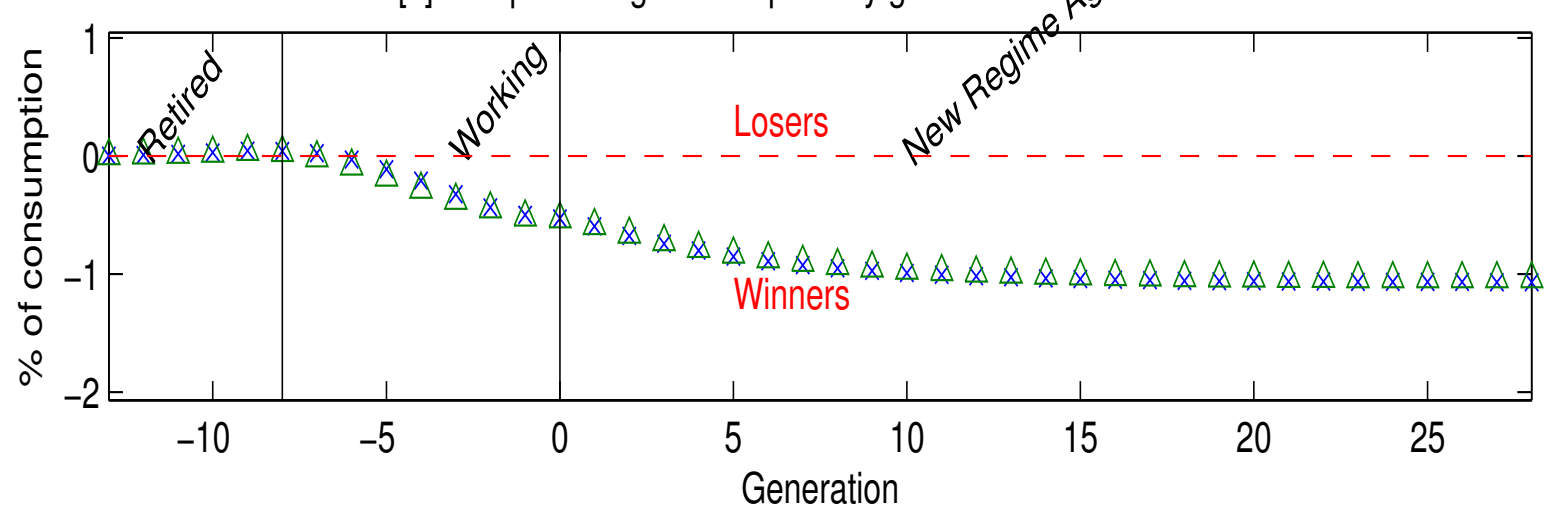

[3] Compensating consumption as \% of GDPover time

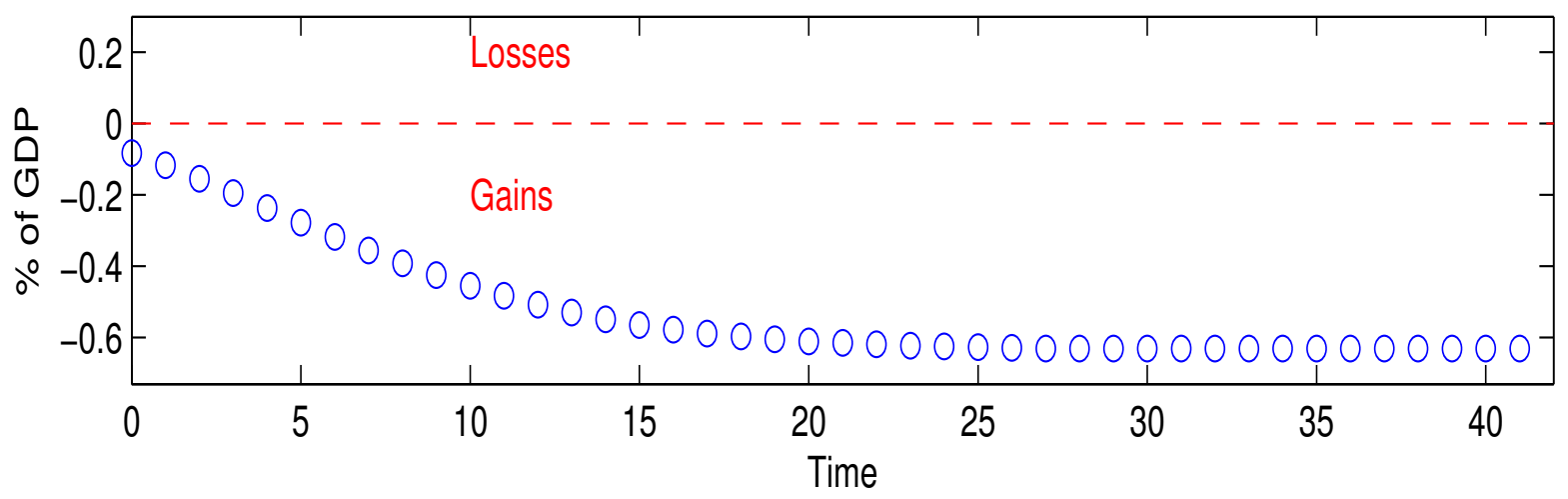

Figure 5: Welfare dynamics: Labor taxes decrease to accommodate the drop in energy subsidies. Panel [1] reports compensating consumption units as percent of per period consumption of each generation for private and public sector workers. Panel [3] reports total compensating consumption as \% of GDP for all generations for each year after the reform. 

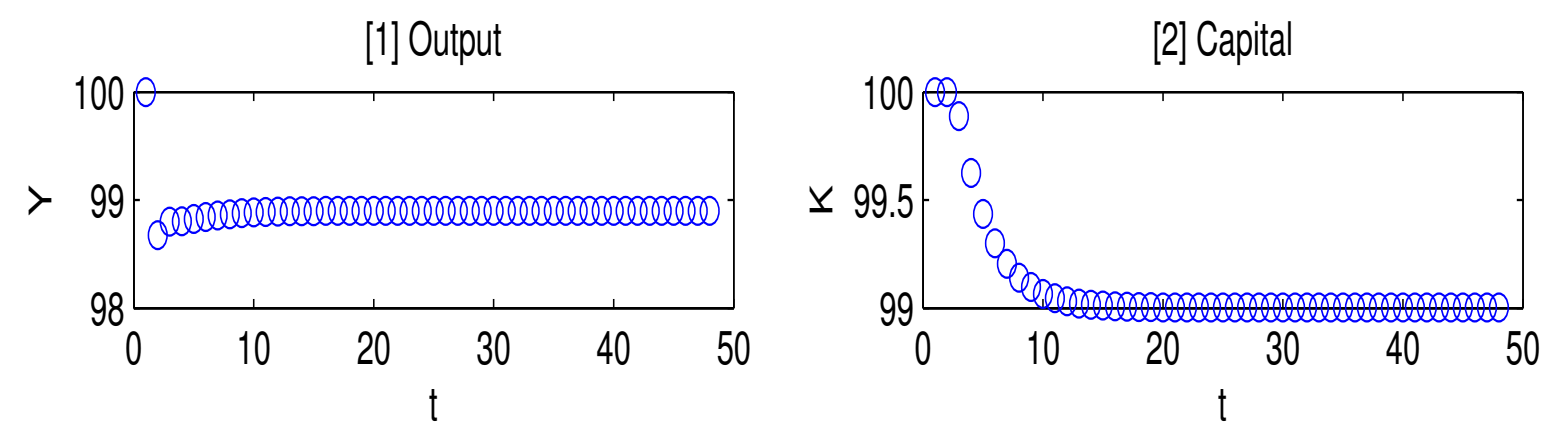

[3] Wages
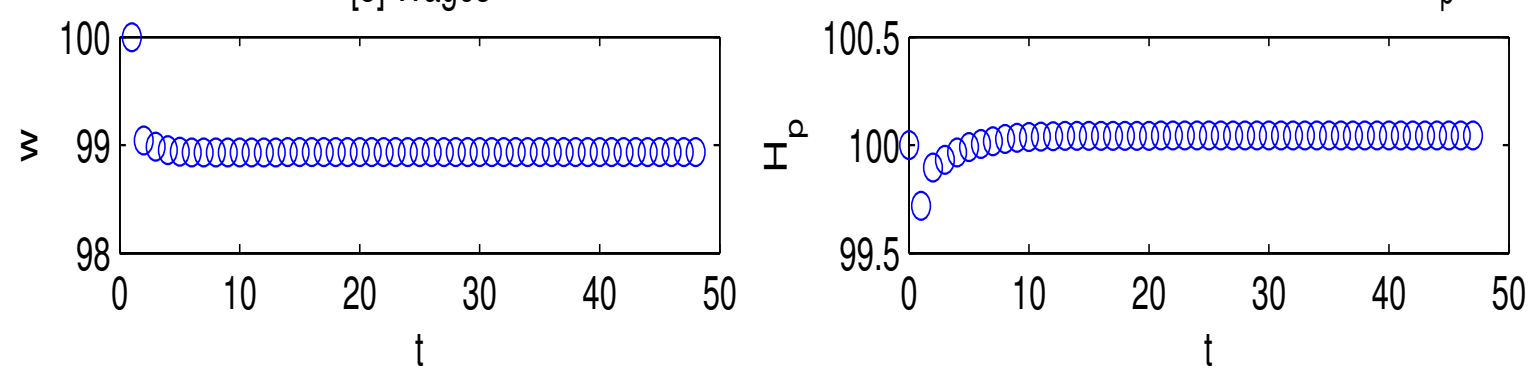

[5] Public sector human capital: $\mathrm{H}_{\mathrm{g}}$
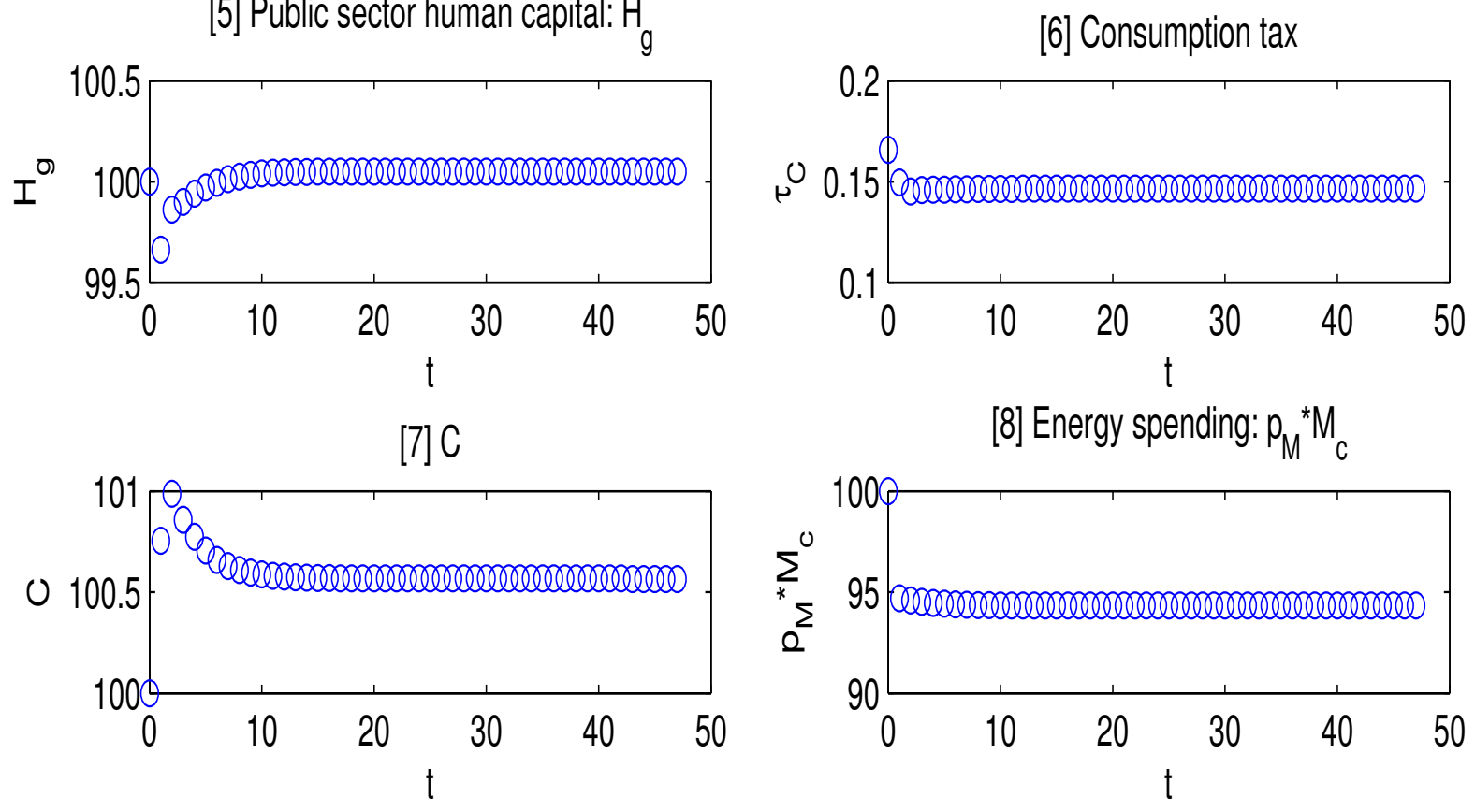

Figure 6: Transitions: Decrease energy subsidies for both, households and producers by $15 \%$ and let consumption taxes decrease to accommodate the drop in energy subsidies. 
[1] Compensating consumption by generation: Pribateste Sector

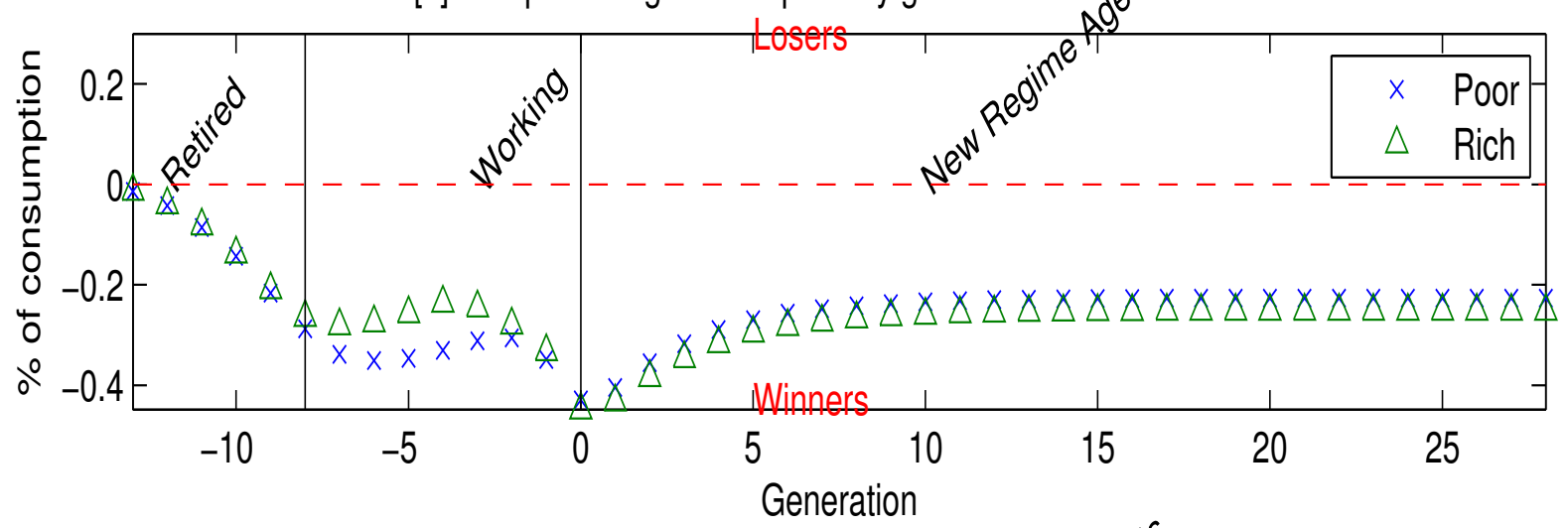

[2] Compensating consumption by generation: Pubitie Sector

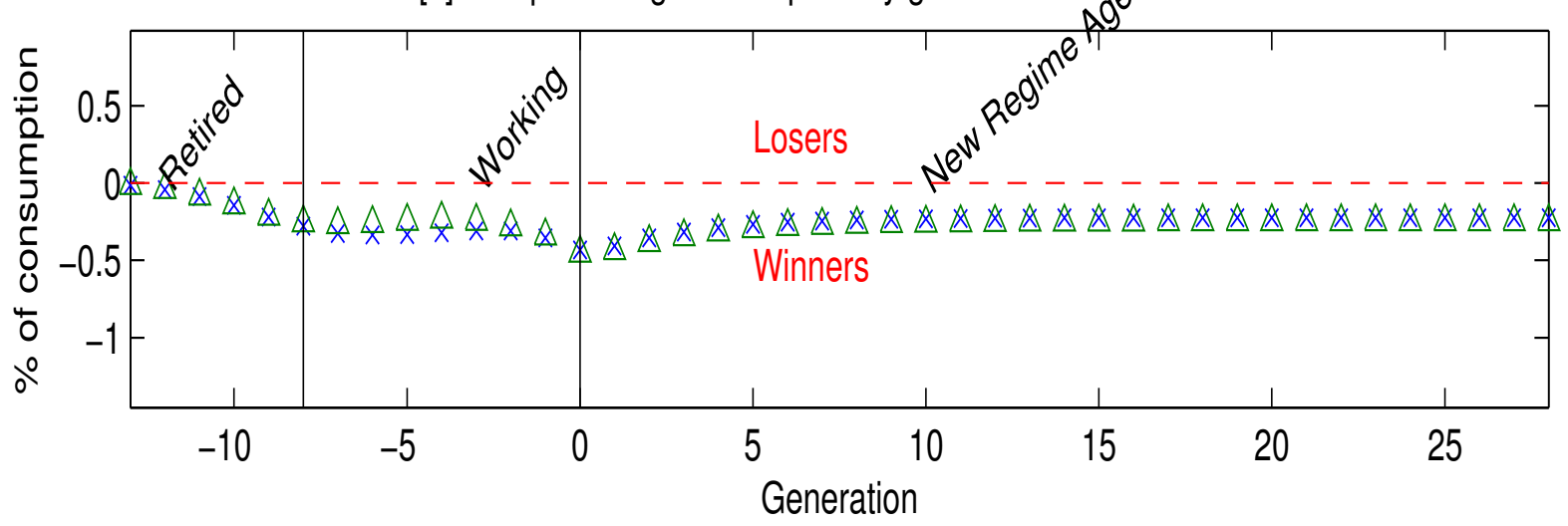

[3] Compensating consumption as $\%$ of GDPover time

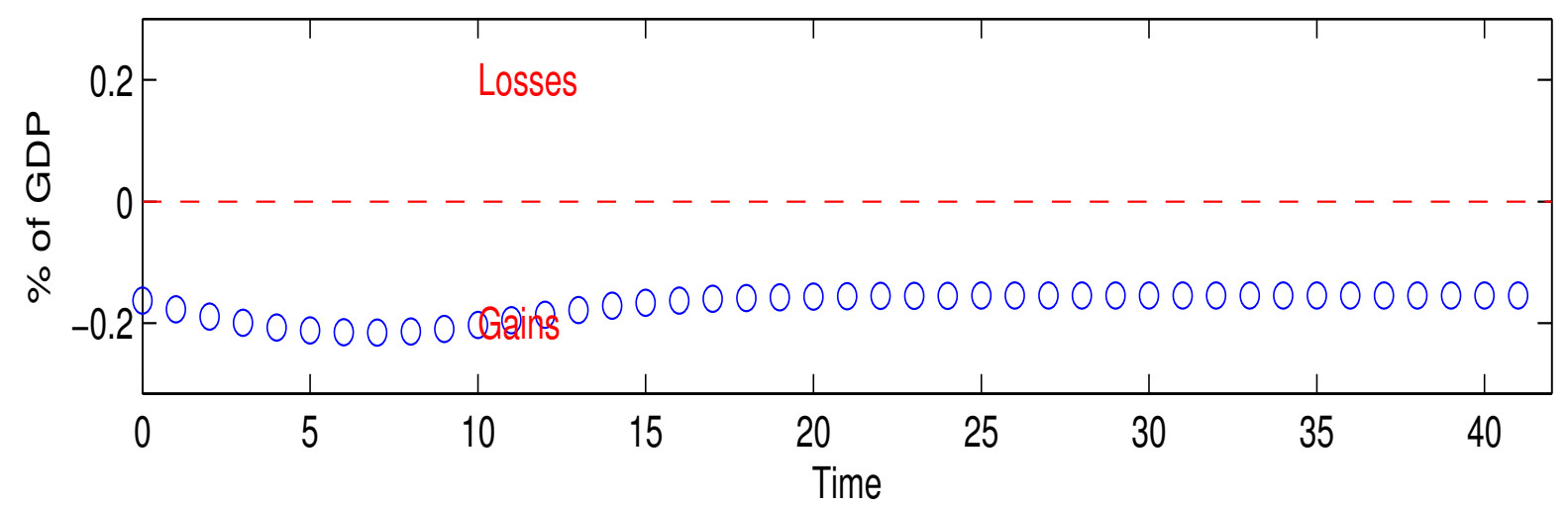

Figure 7: Welfare dynamics: Decrease energy subsidies for both, households and producers by $15 \%$ and let consumption taxes decrease to accommodate the drop in energy subsidies. Panel [1] reports compensating consumption units as percent of per period consumption of each generation for private and public sector workers. Panel [3] reports total compensating consumption as \% of GDP for all generations for each year after the reform. 